\title{
Microfluidic Platforms to Unravel Mysteries of Alzheimer's Disease: How Far Have We Come?
}

\author{
Pragya Prasanna ${ }^{1, *}$, Shweta Rathee ${ }^{2}$, Vedanabhatla Rahul ${ }^{3}$, Debabrata Mandal ${ }^{4}(\mathbb{D}$, \\ Macherla Sharath Chandra Goud ${ }^{1}$, Pardeep Yadav ${ }^{5}$, Susan Hawthorne ${ }^{6}$ D, Ankur Sharma ${ }^{7}$, \\ Piyush Kumar Gupta ${ }^{7}$, Shreesh Ojha ${ }^{8} \mathbb{D}_{\text {, Niraj Kumar Jha }}{ }^{\sqrt[D]{ }}$, Chiara Villa ${ }^{9}$ (D) and Saurabh Kumar Jha ${ }^{5, *}$
}

1 School of Applied Sciences, KK University, Nalanda 803115, Bihar, India; mscgoud1234@gmail.com

2 Department of Food Science and Technology, National Institute of Food Technology, Entrepreneurship and Management, Sonipat 131028, Haryana, India; shweta.r@niftem.ac.in

3 Department of Mechanical Engineering, National Institute of Technology, Rourkela 769008, Odisha, India; vrahul1803@gmail.com

4 Department of Biotechnology, National Institute of Pharmaceutical Education and Research, Hajipur 844101, Bihar, India; debabrataman@gmail.com

5 Department of Biotechnology, School of Engineering and Technology (SET), Sharda University, Greater Noida 201310, Uttar Pradesh, India; par.yadav2011@gmail.com (P.Y.); niraj.jha@sharda.ac.in (N.K.J.)

6 School of Pharmacy and Pharmaceutical Sciences, Ulster University, Cromore Road, Coleraine, Co., Londonderry BT52 1SA, UK; s.hawthorne@ulster.ac.uk

7 Department of Life Sciences, School of Basic Science and Research (SBSR), Sharda University, Greater Noida 201310, Uttar Pradesh, India; ankur.sharma7@sharda.ac.in (A.S.); dr.piyushkgupta@gmail.com (P.K.G.)

check for updates

Citation: Prasanna, P.; Rathee, S.; Rahul, V.; Mandal, D.; Chandra Goud, M.S.; Yadav, P.; Hawthorne, S.;

Sharma, A.; Gupta, P.K.; Ojha, S.; et al. Microfluidic Platforms to Unravel Mysteries of Alzheimer's Disease: How Far Have We Come? Life 2021, 11, 1022. https://doi.org/10.3390/ life11101022

Academic Editor: Ramón Cacabelos

Received: 21 August 2021

Accepted: 20 September 2021

Published: 28 September 2021

Publisher's Note: MDPI stays neutral with regard to jurisdictional claims in published maps and institutional affiliations.

Copyright: (c) 2021 by the authors. Licensee MDPI, Basel, Switzerland. This article is an open access article distributed under the terms and conditions of the Creative Commons Attribution (CC BY) license (https:// creativecommons.org/licenses/by/ $4.0 /)$.
8 Department of Pharmacology and Therapeutics, College of Medicine and Health Sciences, P.O. Box 17666, United Arab Emirates University, Al Ain 15551, United Arab Emirates; shreeshojha@uaeu.ac.ae

9 School of Medicine and Surgery, University of Milano-Bicocca, 20900 Monza, Italy; chiara.villa@unimib.it

* Correspondence: pragyaprasanna36@gmail.com or pragyaprasanna2019@gmail.com (P.P.); Saurabh.jha@sharda.ac.in (S.K.J.)

Abstract: Alzheimer's disease (AD) is a significant health concern with enormous social and economic impact globally. The gradual deterioration of cognitive functions and irreversible neuronal losses are primary features of the disease. Even after decades of research, most therapeutic options are merely symptomatic, and drugs in clinical practice present numerous side effects. Lack of effective diagnostic techniques prevents the early prognosis of disease, resulting in a gradual deterioration in the quality of life. Furthermore, the mechanism of cognitive impairment and AD pathophysiology is poorly understood. Microfluidics exploits different microscale properties of fluids to mimic environments on microfluidic chip-like devices. These miniature multichambered devices can be used to grow cells and 3D tissues in vitro, analyze cell-to-cell communication, decipher the roles of neural cells such as microglia, and gain insights into AD pathophysiology. This review focuses on the applications and impact of microfluidics on AD research. We discuss the technical challenges and possible solutions provided by this new cutting-edge technique to understand disease-associated pathways and mechanisms.

Keywords: Alzheimer's disease; microfluidics; lab-on-chip; 3D culture; organ-on-chip

\section{Introduction}

Alzheimer's disease (AD) is a chronic neurodegenerative condition in which cognition and memory formation decline progressively due to an irreversible loss of neurons in the hippocampus and cortex regions [1]. It is characterized by the extracellular formation of senile plaque mainly constituted by amyloid-beta 42 (A $\beta 42)$ peptide and intracellular neurofibrillary tangles (NFTs), composed of hyper-phosphorylated paired helical filaments of the microtubule-associated protein tau (MAPT) [2-4]. Apart from A $\beta$ and tau pathology, processes such as impaired synaptic functions, neurotransmission dysfunction, and 
microglia-mediated inflammation play a key role in AD pathogenesis [5]. Primary symptoms of the disease comprise memory deterioration, apathy, depression, and changes in personality and behavior that finally require full-time medical care [6]. The majority of AD cases present as a late-onset sporadic form (SAD) occurring in individuals aged 65 or older. SAD shows a complex etiology and results from a combination of genetic and environmental influences. To date, the only confirmed genetic risk is represented by the presence of the $\varepsilon 4$ allele of Apolipoprotein $\mathrm{E}$ (ApoE), the main carrier of cholesterol in the central nervous system (CNS). This variant accelerates the onset of AD by enhancing the $\mathrm{A} \beta$ deposition into plaques and reducing its clearance from the cerebral tissue [7]. On the contrary, the rare early-onset forms of AD are familiar with FAD with an autosomal dominant pattern of inheritance in one of the known genes, APP, PSEN1, and PSEN2, encoding the $\mathrm{A} \beta$ precursor protein (APP), presenilin-1, and presenilin-2, respectively. As all of these are involved in the maturation and processing of APP, mutations in these genes result in increased production or aggregation of $\mathrm{A} \beta$ peptides [8]. The 'World Alzheimer Report 2019 ' shows that $\mathrm{AD}$ accounts for more than $70 \%$ of the total dementia cases diagnosed worldwide [9,10], therefore an early diagnosis of $\mathrm{AD}$ is crucial for disease management [11].

Despite AD prevalence and many years of research, several aspects of its complex etiology remain unexplored [12,13]. Moreover, the current therapeutic strategies are merely symptomatic, attenuating only behavioral symptoms but presenting several side-effects such as confusion, dizziness, depression, constipation, and diarrhea, reported in most medications [14]. Therefore, a more in-depth understanding of the molecular mechanisms underlying $\mathrm{AD}$ pathogenesis, revisiting numerous existing concepts, and effective screening for therapies aimed at halting or preventing neurodegeneration in $\mathrm{AD}$ is required $[15,16]$. The lack of suitable experimental models has also presented a bottleneck in understanding the AD pathological mechanism. Moreover, widely accepted notions such as the deposition of $A \beta$ and hyperphosphorylation of microtubular protein tau also lack a direct correlation between the deposition or phosphorylation and the disease progression $[17,18]$.

In recent years, microfluidics is emerging as an economical and versatile platform for biologists to mimic and control the cellular microenvironment in order to model diseases, study cell behavior from single- to multi-cellular organism level, and develop multiple experiments in miniaturized devices suitable for diagnostics, biomedical analysis, pathological studies of neural degeneration and drug developments $[19,20]$. These devices are popular, especially for their flexibility of design, experimental flexibility, leverage of a sufficient number of controls, handling single cells, controlled co-culture, reduced reagent consumption, reduced contamination risk, and efficient high throughput experimentation.

The past decade has witnessed a surge in the use of microfluidics technology in neurodegenerative diseases to gradually minimize biomedical research dependence on in vivo models [21]. These platforms have been widely implicated in growing 3D gels that could be further applied in producing a three-dimensional tissue representative of human organs. With the help of these miniaturized devices, the growth of neurons, astrocytes, and microglia have also been facilitated in the form of triculture models [22]. This review describes the latest advances in the progress of microfluidics technologies and elaborates various ways through which the domain of microfluidics presents solutions to the management of neurodegenerative disease, with a particular focus on AD. First, we emphasized the applications of microfluidics in the study of disease pathophysiology and the early detection of $\mathrm{AD}$ with the help of known biomarkers at a miniaturized level. Subsequently, we examined the impact of microfluidics on accelerating AD research. We then discussed the possible challenges that this field needs to overcome and the directions to be taken before realizing its full-fledged application in the AD field.

\section{Revisiting Alzheimer's Disease: What Is Known?}

\subsection{History}

AD was first diagnosed by a German psychiatrist and neuropathologist, Alois Alzheimer, in 1906 [16]. However, after 1907, the behavioral and physiological changes in AD and 
naturally occurring senility and dementia were differentiated [23]. Symptoms such as failure of storage and retrieval of memory, confusion, and poor judgment have been categorized as characteristic features of AD. Other symptoms include language disturbance, agitation, withdrawal, and hallucinations followed by occasional seizures, increased muscle tone, and mutism $[1,9,10,12]$. Even after decades of research, the social and economic impact of the disease has not decreased, and the projections of the World Alzheimer Report 2019 predict more than 150 million cases by 2050 [9,10,12]. Due to remarkable advances in science and technology, increased understanding of the disease pathophysiology and causes has led to improved diagnosis and treatment $[13,24]$.

\subsection{Causes}

Several hypotheses have been proposed to define the etiology of AD based on observed clinical, neuropathological features: cholinergic hypothesis, amyloid cascade hypothesis, and tau propagation hypothesis [25]. Some other potential hallmarks of Alzheimer's dementia are mitochondrial dysfunction, calcium deregulation, neurovascular disintegration, neuroinflammation, metal ion dyshomeostasis, and defective lymphatic system $[9,26-28]$. However, the most well-known and defining features representing AD are $A \beta$ accumulation, phosphorylated tau aggregation, and neuroinflammation $[1,29,30]$. In Figure 1, we have summarized the various AD hallmarks in the Alzheimer's brain and have shown how excessive amyloid deposition leads to neuronal disease. As mentioned above, the amyloid cascade hypothesis postulates that APP metabolism and A $\beta 42$ accumulation are the most important triggering factors for AD pathogenesis [31]. This hypothesis holds the accumulation of $A \beta$ peptide responsible for the eventual loss of synapses and neuronal cell death $[3,28]$. An increasing body of evidence supports toxic $A \beta$ as the primary cause of pathology, which can initiate neuronal dysfunction by inducing granulovacuolar degeneration, astrocytosis, microgliosis, and deficient endosomal transport when deposited extracellularly [32]. Moreover, the A $\beta$ can also deposit around the small blood vessels of the brain, leading to the development of cerebral amyloid angiopathy (CAA), a common neuropathological condition usually occurring in $\mathrm{AD}$ patients, probably caused by the failure of $A \beta$ clearance [33].

Tau hypothesis correlates AD pathology with the hyperphosphorylation and intracellular deposition of neurofibrillary tangles (NFTs) of microtubular protein tau [17]. It further elucidates that the propagation of the pathological form of tau protein from one neuron to another may drive the disease aggressively. Few studies linking both the above hypotheses highlight that aggregation of amyloid plaques leads to the activation of vaious kinases, causing hyperphosphorylation of the tau protein [18]. The deposition of plaques and NFTs initiate a neuroinflammatory response by activating microglia and astrocytes that detect aggregated proteins and promote the release of pro-inflammatory cytokines such as interleukin (IL)-1 $\beta$, IL-6, and tumor necrosis factor (TNF)- $\alpha$, as well as reactive oxygen species (ROS), giving rise to a chronic inflammatory process [34-37]. The link between $A \beta$ and tau aggregation may be related to microglia activation. Indeed, it has been reported that soluble $A \beta$ oligomers can activate microglial cells that in turn promote the hyperphosphorylation of tau with the subsequent formation of NFTs via cytokine release [38]. In addition to microglia and astrocytes, recent evidence has suggested that oligodendrocytes can also play a role in AD pathogenesis. Several cellular processes such as neuroinflammation and oxidative stress may trigger oligodendrocyte dysfunction and $\mathrm{A} \beta$ can impair the maturation of oligodendrocyte progenitor cells and the consequent formation of the myelin sheath [39]. Furthermore, the neuroinflammation and dysfunction of the blood-brain barrier (BBB) resulting from enhanced permeability and reduced expression of tight junction proteins due to increased production of $A \beta$, overexpression of matrix metalloproteinases (MMP)-2/-9, and ApoE, are also often independently linked with AD pathogenesis [40-44]. 


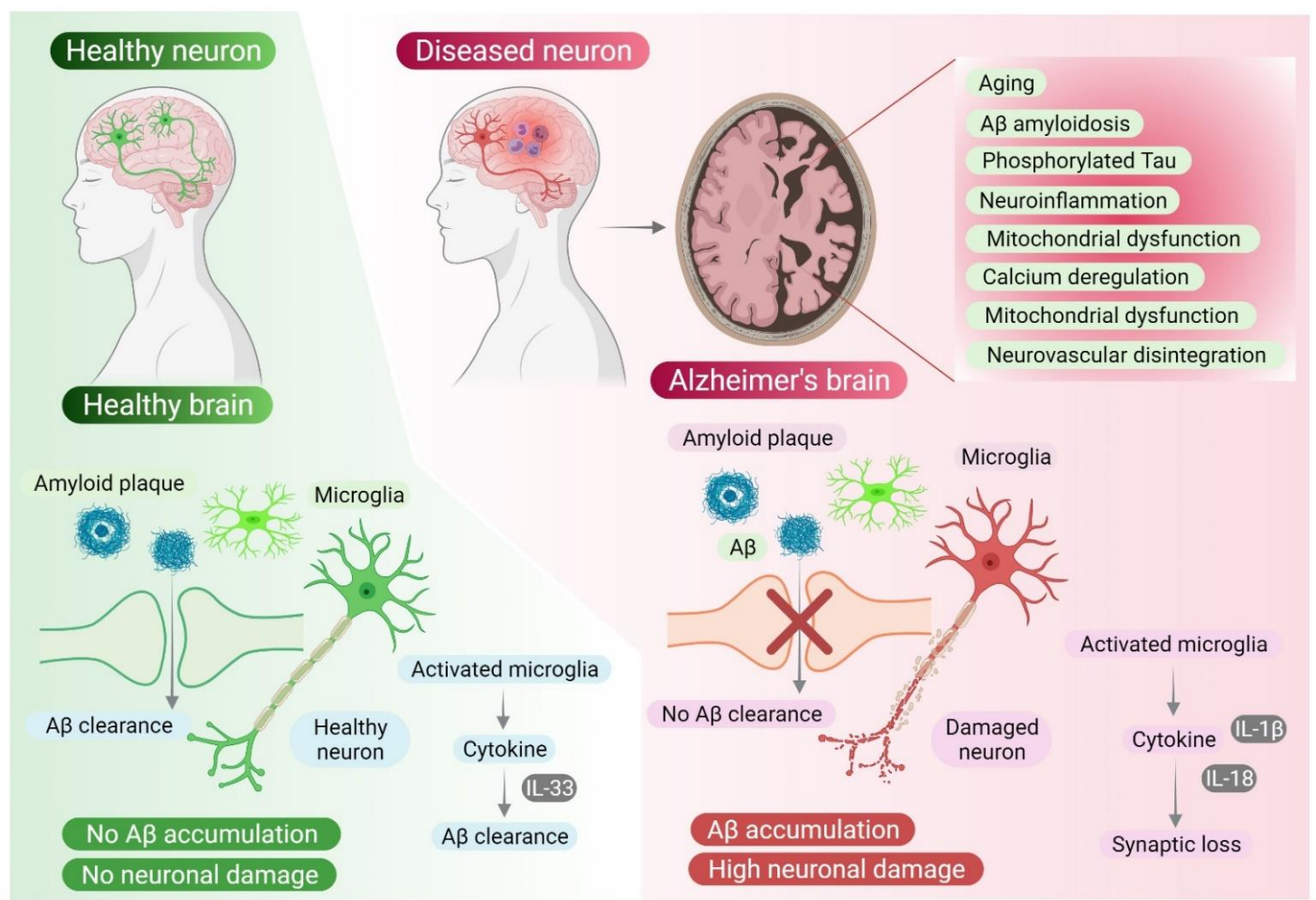

Figure 1. The pathophysiology of Alzheimer's disease is very complex. Major pathological hallmarks of Alzheimer's disease are provided. Among all the hallmarks, A $\beta$ accumulation is considered the major cause of neurodegeneration in Alzheimer's disease. It has been found that all other causes such as tau pathology and/or neuroinflammation ultimately converge to $A \beta$ accumulation. For instance, microglia, the innate immune system of the nervous system, mediates neuroinflammation by the production of cytokines such as IL33, IL-8 and IL-1 $\beta$. Microglial activation initiates inflammation of the neural tissues. The cytokines (IL-33) produced in the due process help in A $\beta$ clearance whereas IL- 8 and IL-1 $\beta$ cause synaptic dysfunction. This molecular mechanism reflects the complex.

\subsection{Diagnostic Biomarkers and Therapeutics}

The definitive diagnosis of $\mathrm{AD}$ is only possible by post-mortem histopathological assessment of extracellular A $\beta$ plaques and intraneuronal NFTs [45]. Although the treatment is mainly supportive with symptoms managed on an individual basis, some of the therapeutic options approved for AD from the FDA include the cholinesterase inhibitors such as donepezil, rivastigmine, galantamine (reversible AChEIs), and memantine (NMDA inhibitor) [14,46-49]. However, the effectiveness of these drugs is often questioned [50]. As the pathological changes silently occur in the brain over years before the onset of symptoms, the current challenge is the search for novel biomarkers for an easy and accurate diagnosis of the disease in its initial stages. The actual diagnostic methods rely on the measures of $\mathrm{A} \beta 42$, phosphorylated ( $\mathrm{p}$-tau), and total tau ( $\mathrm{t}$-tau) protein levels in the cerebrospinal fluid (CSF) of patients, in combination with advanced neuroimaging techniques such as magnetic resonance imaging (MRI) and positron emission tomography [51]. Different reliable biomarkers comprising several signaling proteins in blood plasma have also been discovered that can detect Alzheimer's with approximately $90 \%$ accuracy even in patients with a mild cognitive impairment (MCI) which may later progress to AD [52]. A similar study with serum proteins, including a disintegrin and metalloprotease 10 (ADAM10), also retained diagnostic accuracy for the early diagnosis of AD [53]. Several blood-based microRNAs (Let-7b and microRNA-206) have also been found to have a strong correlation with cognitive decline and may be used as predictive biomarkers for AD [54]. Although promising, the use of these blood biomarkers in the clinical setting requires validation in further studies and standardization of pre-analytical sample processing and different methods. 


\section{Unsolved Mysteries in Alzheimer's Disease Research}

There are long-standing differences in opinion regarding the roles of soluble $A \beta$ fibrils and tau tangles in ameliorating neurotoxicity, inflammation, and AD initiation. Due to the overrated role of amyloids in AD pathology, immunization against $A \beta$ was presumed to be an effective strategy, which unfortunately failed to deliver expected outcomes in clinical trials $[30,55]$. In subsequent studies, failure to reverse AD pathology following $A \beta 42$ targeting or delaying plaque formation led researchers to believe that $A \beta 42$ deposition is not the sole reason for $\mathrm{AD}$ pathogenesis [56]. Nonetheless, this observation and other findings, such as genetic mutations in presenilin-1/-2 and abnormal APP processing in AD, emphasized a significant shift in the focus towards alternative theories $[57,58]$.

The believers in tauopathy also have found challenges in establishing the correlation between the biochemical observations of tau tangles and the clinical progression of the disease in the patients [59]. The specific tau species involved in neurotoxicity are ambiguous and arduous to decipher from the results obtained in the macroscopic experimental setup [60]. Recent evidence indicates that it is not only the amyloid plaques but also the intermediate amyloidic species and oligomeric assemblies that are neurotoxic and may exaggerate the disease pathology $[61,62]$. The major drawback experienced in the current laboratory practices is that it is incapable of assessing these deleterious oligomeric assemblies due to the problems associated with its separation from the $A \beta$.

The absence of validated biomarkers, probably due to the inconsistent results produced due to analytical hindrances such as epitope masking and lack of reproducibility, prevents early detection of disease symptoms and poses additional challenges $[63,64]$. More robust investigation of genetic risk factors, the mechanism of receptor-mediated transport of $A \beta$ and the role of interstitial fluid in regulating the metabolism of $A \beta$ in vitro models need to be determined.

Activation of astrocytes leads to an exacerbated immune response causing neuronal damage and degeneration [65]. Contemporary experimental approaches involve mutant or transgenic animals with disease pathology leading to immense animal mortality [66].

Recently, exosomes have gained considerable attention both as a drug delivery system and a significant biomarker for diagnostics by offering prognostic information $[67,68]$. These small membrane-bound extracellular vesicles are ubiquitously released from eukaryotic cells to carry and deliver proteins, lipids, and nucleic acids, to the target cells [67]. Though most studies substantiate the benefits of exosomes in the clearance of proteotoxic burden by transferring neuroprotective substances between neural cells, recent findings revealed that exosomes are also involved in the transportation of protein aggregates involved in different neurodegenerative diseases $[67,69]$. Furthermore, these loaded moieties play a crucial role in $\mathrm{AD}$ pathology by spreading $\mathrm{A} \beta$ and hyperphosphorylated tau, inducing oxidative/proteotoxic stresses, neuroinflammation, and neuronal loss [68-70]. Since exosomes may prove to be a significant biomarker, better techniques are required to isolate exosomes at a large scale and perform experiments at a co-culture level. However, for the successful implication of these nanovesicles in the domain of exosomes, extensive research is required to ascertain the probable route of administration and safety aspects for clinical application.

\section{Cellular and Animal Models of AD}

\subsection{In Vitro Models}

The study of $\mathrm{AD}$ in vitro has been largely used to elucidate disease pathogenesis at molecular and cellular levels as well as for drug screening and discovery. Different cellular models have been developed to study various aspects of AD, including primary cultures, cancer cell lines, and induced pluripotent stem cells (iPSCs). However, cell culture systems cannot recapitulate the complex environment of the human brain and the interactions with other non-neuronal cells [71]. 


\subsubsection{Primary Cell Lines}

Primary cell lines can be derived from transgenic animal or human patients. The major advantages in the use of these cultures rely on their easy availability and the potential to obtain different cell types, including specific neuron subtypes. Primary cultures have been extensively used to investigate the role of $A \beta$ pathology both in astrocytes [72] and microglia [73]. Primary neurons, mainly derived from the hippocampus and cortex, were also employed to examine the neuroprotection mechanisms and the effect of $A \beta$ oligomers on neuron function and apoptosis [74], as well as to reproduce the pathophysiological events occurring in $\mathrm{AD}$, such as inflammation, altered signal pathways or epigenetic changes.

\subsubsection{Human Neuroblastoma (SH-SY5Y) Cell Lines}

Originally isolated from human bone marrow with neuroblastoma, SH-SY5Y cells are derived from a neuronal lineage in its immature stage. According to the treatment, this cell line can differentiate into several various neural lineages which phenotypically resemble mature neuron-like features, including decreased proliferation rate, neuronal morphology, and expression of neuron-specific markers [75]. In regard to AD, SH-SY5Y cells can be modified to model some pathological aspects of the disease, such as neurodegeneration after exposure to $\mathrm{A} \beta$ oligomers [76], oxidative stress [77] and apoptosis [78], as well as to better understand the role of ApoE in $\mathrm{AD}$ [79]. Although this model has the potential to study the known molecular mechanisms associated with $\mathrm{AD}$, it cannot fully recapitulate specific characteristics of the sporadic forms of the disease and age-dependent risk factors.

\subsection{3. iPSCs-Based Models of AD}

Recent advances in iPSC technology have revolutionized the study of neurodegenerative disorders, given the limited access to living cells from brain patients. Reprogrammed from mature somatic cells of both familial (FAD) and sporadic AD (SAD) individuals, iPSCs can be differentiated into different disease-relevant cell types, maintaining the patient's precise genome. The majority of studies performed on iPSC-derived neurons from fibroblasts of FAD and SAD patients showed high levels of $A \beta 42$ and response to $\beta$ - and $\gamma$-secretase inhibitors [80-82], as well as increased hyperphosphorylated tau, the two main pathological hallmarks of AD [81,83]. Regarding other cell types, iPSC-derived astrocytes from $\mathrm{AD}$ patients displayed severe pathology and dysfunction [84]. Additionally, iPSCs have also been used to investigate the role of the ApoE $\varepsilon 4$ allele in different cell types, including neurons, astrocytes and microglia [85]. The inherent limitations of iPSC-derived two-dimensional (2D) cultures can be partially overcome by the generation of three-dimensional (3D) organoids, complex self-organized aggregates of different cell types derived from iPSCs that closely mimic the complexity of the brain's architecture. Regarding AD, 3D cerebral organoids successfully recapitulate $\mathrm{A} \beta$ deposits, tau pathology and neuroinflammation [86,87].

\subsection{In Vivo Models}

In recent decades, different experimental models in various species have been generated to replicate AD pathology. Invertebrate animal models, including Caenorhabditis elegans, Danio rerio, or Drosophila melanogaster, have been selected for their short lifespan, well-characterized development and behavior [71]. However, mammalian models, especially mice, have been commonly used in AD research due to their similar anatomy to humans and easy manipulation [71].

\subsubsection{Transgenic Animal Models of AD}

Since the discovery of AD-associated genes, different transgenic animal models have been generated by introducing the human mutant gene into the animal genome or by deleting a specific gene from the animal genome to develop the pathological hallmarks of $\mathrm{AD}$. Many transgenic mouse models have been developed so far, harboring mutations in the 
APP, presenilin (PSEN1, PSEN2), MAPT genes or in combination (APP/Tau, APP/PSEN1 double transgenic mice, APP/Tau/PSEN1 triple transgenic mice (3xTg-AD) and five transgenic mice (5xFAD). However, these models do not reproduce all AD pathological features, as they mimic the genetic forms of AD without giving any information on sporadic AD. Single transgenic mouse overexpressing different mutations in APP gene and APP/PSEN1 double transgenic mice exhibited $\mathrm{A} \beta$ plaques and cognitive deficits but failed to develop NFTs, whereas the tau transgenic model showed NFTs, neuronal loss, and behavioral and motor impairments without developing $A \beta$ plaques [88]. The two features of AD pathology were recapitulated with the generation of the APP/Tau double transgenic mice that displayed $\mathrm{A} \beta$ deposition, NFTs and motor deficits, representing a candidate tool to investigate the interaction between $\mathrm{A} \beta$ and tau protein. Compared to single and double transgenic models, the 3xTg-AD harboring mutations in APP, PSEN1 and MAPT genes exhibited more severe pathology but slow development of $A \beta$ [89]. To accelerate the plaque formation, 5xFAD mice co-expressed five AD-linked mutations in human APP and PSEN1 genes, showing thus an early amyloid pathology, but lacking NFTs [90].

As ApoE represents the genetic risk factor for sporadic AD, transgenic, knock-in and knock-out mice expressing human APOE genes have been generated to investigate the mechanisms occurring in SAD. Knock-in mice expressing the human form of ApoE $\varepsilon 4$ allele exhibited cognitive deficits [91] and high deposition of plaque or exacerbated tau-mediated neurodegeneration when crossed with APP or tau transgenic mice, respectively [92,93].

\subsubsection{Non-Transgenic Animal Models of AD}

Non-transgenic animal models are used not only to study the classical AD hallmarks but also to model other pathological mechanisms, including oxidative stress, apoptosis, synaptic dysfunction, neuroinflammation, alterations in gut microbiota-brain axis, or autophagy [94]. As memory deficits and cognition loss are common traits of aged animals ranging from rodents to non-human primates, they can be used as a natural model of $\mathrm{AD}$. Among them, the senescence-accelerated mouse-prone 8 (SAMP8) displayed age-related learning and memory decline as well as most features related to AD pathogenesis, such as oxidative stress, inflammation, A $\beta$ plaques, NFTs, altered autophagy activity, and intestinal flora disruption, representing thus an ideal model to study this disorder [95]. Alternatively, animals can also be induced to develop $\mathrm{AD}$ by cerebral injection with $\mathrm{A} \beta$ synthetic peptide or other chemicals, by administering a high-fat diet to resemble metabolic abnormalities associated with $\mathrm{AD}$, or generating radiofrequency lesions to the brain to induce cognitive deficiencies [88].

\section{Microfluidics: An Overview and Biological Applications}

The interdisciplinary field of microfluidics, derived from molecular biology, molecular analysis, and microelectronics, emerged in the late 1980s [96]. A timeline of the development of microfluidics from these physical and chemical innovations to its application in biological research has been provided in Figure 2. The emergence of this field began after discovering physical techniques such as photolithography and soft-lithography, later used for the fabrication of chips, and is still evolving with further technological advancements. The emergence of fabrication techniques facilitated the design and fabrication of chip-like 3D structures from solid substrates such as glass, silica, thermoplastics, etc. [96-99]. The first microfluidic devices or chips were made of silicon and glass. Still, due to their brittle nature, low gas permeability, and costly fabrication methods, they have never been considered an attractive option in microfluidics. Investigating alternative materials that could be optically transparent, easy to process, flexible, and comparatively cheap resulted in the discovery of several materials, which have been examined to date for the making of microfluidic devices (Table 1). 


\section{Timeline of the progress of microfluidics in biomedical research}

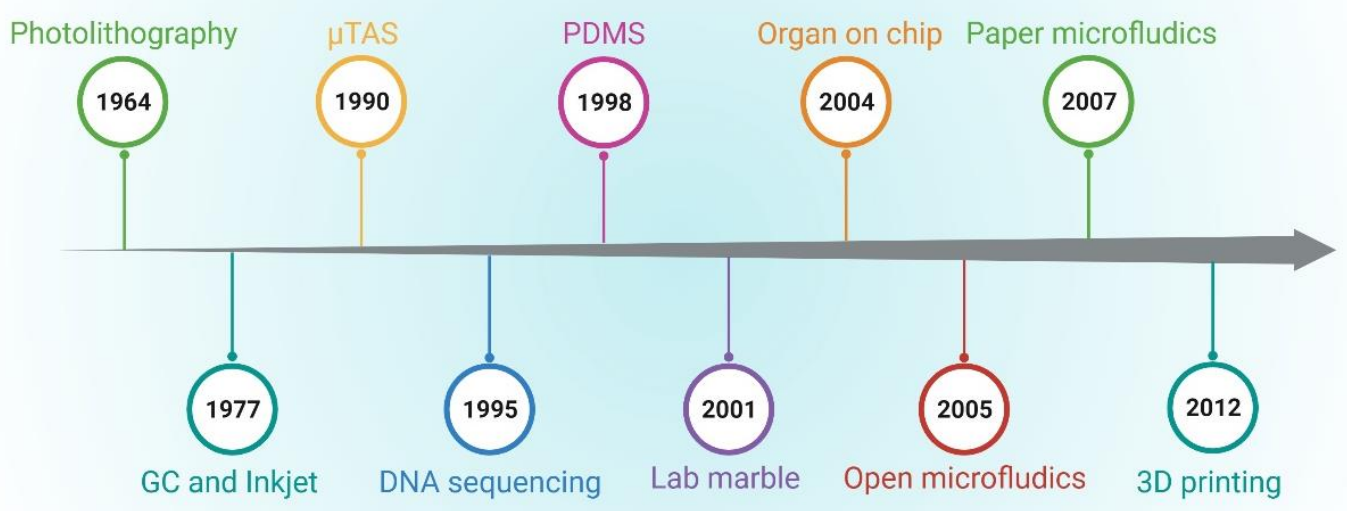

Figure 2. Timeline of the progress of microfluidics in biomedical research. Abbreviations: GC, gas chromatography; $\mu$ TAS, micro total analysis system; PDMS, Polydimethylsiloxane.

For the materials used in designing microfluidic devices, polydimethylsiloxane (PDMS), an elastomer introduced in the 1990s, is a material of choice for cell co-cultures [99-102]. As PDMS is compatible with cells, microfluidic devices made from it started to be used for cell biology applications and studies of co-cultures [98,103]. Technology is usually characterized as an engineering subject. Still, the implementation of the proof-of-concept experiments in the domain of microfluidics serves biologists and clinicians in enhancing capabilities in their everyday research. This technology allows the manipulation of small fluid volumes in a fabricated microscale system and has emerged as an excellent tool in modern biology. These microscale, multichambered tiny devices can grow cells and 3D tissues for biology research [20] and has enabled us to recreate experimental conditions at microscopic levels. This allows manipulation of biological specimens and cells at extraordinary spatiotemporal resolution and reveals otherwise hidden mechanistic insights, leading to a range of biological applications [104]. Properties such as rapid sample processing and precise control of fluids in microfluidic technologies have presented an attractive way to replace traditional experimental approaches. The microliter volumes of reagents mobile in laminar flow match with the biological microenvironments. Multiple diverse biochemical assays can be performed in a small volume, and the flow control feature at the micron level allows for improvement over the traditional macroscale assays. This is widely used in the imaging, bioinformatics, and molecular biology approaches [105,106]. Integration of fluid handling and signal detection features in microfluidics has allowed us to design cheaper yet sensitive point-of-care assay devices for different infectious diseases such as cancer, AIDS, malaria, SARS, dengue, etc. [107-109]. Even paper-based microfluidics such as DNA diagnostics have been developed in recent years, which are low-cost, multiplexed diagnostics [110].

Liquid marble (LM) is also a new type of digital microfluidics (DMF) that can be employed in a variety of biological applications. Cryoprotectant-free cryopreservation of mammalian cells using LM-based digital microfluidics is a potential method. This opens up new ways to cryopreserve rare biological samples without the risk of cryoprotectants causing toxicity [111]. LM can also be utilized for diagnostic testing, cell culture, and drug screening in the biomedical area [112]. DMF, a novel multifunctional microfluidics technology, offers a great deal of potential in the automation and miniaturization fields. In DMF, discrete droplets containing samples and reagents are controlled to implement a series of operations via electrowetting-on-dielectric. This process works by applying electrical potentials to an array of electrodes coated with a hydrophobic dielectric layer. DMF, unlike microchannels, allows for exact control of various reaction processes without 
the need for complicated pump, microvalve, and tubing networks. Other distinguishing characteristics of DMF include portability, lower sample consumption, faster chemical reaction time, versatility, and better integration with other technology types. DMF has been used in a wide range of fields (including chemistry, biology, medicine, and the environment) due to its distinct advantages [113]. Droplet-based microfluidics, which can be employed in drug discovery, transcriptomics, and high-throughput molecular genetics, has recently been reported. This enables researchers to work with relatively limited materials, such as primary cells, patient biopsies, or expensive reagents, and to perform tests at very high throughput (up to thousands of samples per second). The ability to undertake largescale genotypic or phenotypic screens at the single-cell level is another advantage of the technology [114].

Isolated brain tissue, particularly brain slices, can be used to investigate neuronal function at the network, cellular, synaptic, and single channel levels. Neuroscientists have perfected ways for maintaining brain slice viability and function, settling on principles that are strikingly similar to the engineers' approach to building microfluidic devices. With respect to brain slices, microfluidic technology may (1) provide better spatiotemporal control over solution flow/drug delivery to specific slice regions; (2) overcome the traditional limitations of conventional interface and submerged slice chambers and improve oxygen/nutrient penetration into slices; and (3) permit successful integration with modern optical and electrophysiological techniques [115]. Tissue culture (brain tissue slice) and drug screening have recently been performed using microfluidic platforms. In a study, microfluidic tissue culture system has been utilized to enable culturing of brain tissue slices for a sufficiently long period (up to 3 weeks) to facilitate studies on integration of neuronal stem cells into brain tissue and differentiation into dopaminergic neurons. This also allows for long-term culturing on a microscope stage for real-time microscopic imaging during neural stem cell integration experiments in brain slices [116]. This method has the potential to improve treatment success rates by identifying possible responders earlier in the treatment process and allowing direct drug testing on patient tissues during the early stages of drug development [117].

Cell-patterning techniques are also useful for neuron function and activity investigation and are one of the clear advantages of using microfluidics. So far, many neuron patterning techniques, such as in-mold patterning (iMP), and gel micropatterning by microcasting, or by laser or protein patterning, have been reported. Many applications, ranging from neurodegenerative research to neural computation, require oriented neuronal networks with controlled connectivity. An efficient, directed, and long-lasting guidance of axons toward their target is required to establish such networks in vitro. However, the best guidance achieved so far relies on confining axons in enclosed micro-channels, making them difficult to investigate further. iMP improves axon confinement efficiency on the tracks by 10 to 100 times, resulting in mm-long, highly regular, and fully accessible on-chip axon arrays. iMP also enables well-defined axon guidance from small populations of multiple neurons confined at predefined places in $\mu \mathrm{m}$-sized wells, thereby opening up new avenues for the construction of complex and precisely regulated neural networks [118]. Gel micropatterning by micro-casting is another neuron patterning approach. By using the repellency of agarose gel toward cell adhesion, patterned cultures of myoblasts and cortical neurons can be prepared. This technology is said to be beneficial for repellency-guided cell patterning in a variety of cell types, with applications in cell-cell interactions and axon guidance. With the repellency of agarose and no specific molecules for cell adherence, this technology is user-friendly and useful not just for micro-molding but also for cellular patterning [119]. Further, Stripe assays have been frequently used as in vitro test systems to investigate the responses of developing axons, as well as migrating cells, to established or novel guidance molecules. Silicon matrices are used to produce striped patterns of active molecules on a surface (referred as a "carpet"), which are then used to culture neurons or any other cell type. Purified proteins were utilized to produce stripe patterns on a silicon matrix [120]. 
Table 1. Properties of materials used in microfluidic chips.

\begin{tabular}{|c|c|c|c|c|c|c|}
\hline Properties & Inorganic Materials & Elastomers & Thermoset & Thermoplastics & Hydrogel & Paper \\
\hline Examples & Silicon/Glass & PDMS & Polyester & $\begin{array}{c}\text { Polyethylene, } \\
\text { Polystyrene } \\
\text { Polycarbonate } \\
\text { Polyurethane, Teflon, } \\
\text { Cyclic Olefin } \\
\text { Co-polymer (COC/COP) }\end{array}$ & $\begin{array}{c}\text { Hyaluronic Acid, Agarose, } \\
\text { PEG-DA, Alginate, PMMA, } \\
\text { And Chitosan }\end{array}$ & - \\
\hline Biological Use & Drug Screening, Assays & Assays, Cell Culture & Capillary & $\begin{array}{l}\text { Electrophoresis, DNA } \\
\text { Sequencing, PCR }\end{array}$ & $\begin{array}{l}\text { Study Cell-Cell and } \\
\text { Cell-Matrix Interaction }\end{array}$ & Diagnostics \\
\hline Young's Modulus & $130-180 / 50-90$ & $\sim 0.0005$ & $2.0-2.7$ & $1.4-4.1$ & Low & $0.0003-0.0025$ \\
\hline $\begin{array}{c}\text { Fabrication } \\
\text { Technique }\end{array}$ & Photolithography & Casting, 3D Printing & $\begin{array}{c}\text { Casting/ } \\
\text { Photopolymerization }\end{array}$ & Thermomoulding & Casting/Photopolymerization & $\begin{array}{l}\text { Photolithography, } \\
\text { Printing }\end{array}$ \\
\hline Valving & Yes & Yes & No & No & Yes & Yes \\
\hline $\begin{array}{c}\text { Channel } \\
\text { Dimension/Profile }\end{array}$ & $<100 \mathrm{~nm} / 3 \mathrm{D}$ & $<1 \mu \mathrm{m} / 3 \mathrm{D}$ & $<100$ nm/Arbitrary 3D & $\sim 100 \mathrm{~nm} / 3 \mathrm{D}$ & $\sim 10 \mu \mathrm{m} / 3 \mathrm{D}$ & $\sim 200 \mu \mathrm{m} / 2 \mathrm{D}$ \\
\hline Thermostability & Very High & Medium & High & Medium-High & Low & Medium \\
\hline $\begin{array}{c}\text { Solvent } \\
\text { Compatibility }\end{array}$ & Very High & Low & High & Medium-High & Low & Medium \\
\hline Hydrophobicity & Hydrophobic & Hydrophobic & Hydrophobic & Hydrophobic & Hydrophilic & Amphiphilic \\
\hline Surface Charge & Very Stable & Stable & Stable & Stable & - & - \\
\hline Transparency & No/High & High & High & Medium-High & Low-Medium & Low \\
\hline Cost & High & Low & High & Low & Medium & Low \\
\hline Disadvantage & High Cost, Brittle & $\begin{array}{l}\text { Protein Adsorption, } \\
\text { Permeability, } \\
\text { Autofluorescence }\end{array}$ & $\begin{array}{l}\text { Rigid, Poor Conductivity, } \\
\text { Non-Recyclable }\end{array}$ & $\begin{array}{l}\text { Low Melting Point, } \\
\text { Brittle }\end{array}$ & $\begin{array}{l}\text { Non-Adherent, Low } \\
\text { Mechanical Strength }\end{array}$ & $\begin{array}{l}\text { Porous, Sample } \\
\text { Consumption }\end{array}$ \\
\hline Reference(s) & {$[121,122]$} & {$[123,124]$} & [125] & [126-128] & {$[129,130]$} & [131] \\
\hline
\end{tabular}


Since the 2000s, organ-on-a-chiptechnology has been widely proposed and engineered on the structure and function of tissues and organs 2000 [132]. However, this has evolved rapidly in the past decade due to advancement in rapid prototyping methods such as 3D printing, widely used to produce 3D scaffolds for tissue engineering and devices mimicking a complex microfluidic environment [133]. The first "human-on-a-chip" cell culture systems to investigate physiological processes and "physiome-on-a-chip" systems to investigate novel compounds and their side effects on the human body have emerged [132,134-136]. The emulation of the pathophysiology of several neurodegenerative diseases in vitro through microfluidic devices has also risen rapidly [137,138]. A comprehensive study of the application of microfluidics in the study of neurodegeneration has been provided in the following sections. Several microfluidic tools available to date are shown in Figure 3.
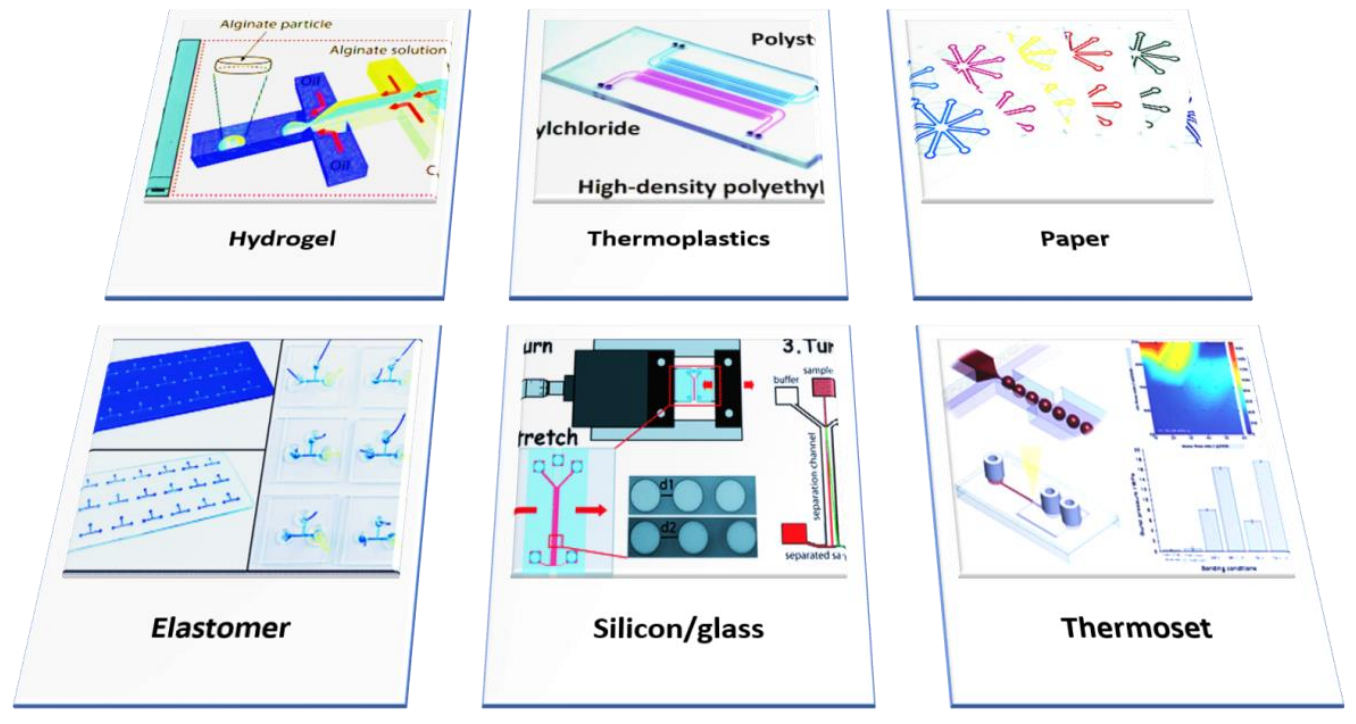

Figure 3. Schematic representation of the materials used for the fabrication of microfluidic chips. Hydrogels made up of natural materials, i.e., alginate, serve as matrices for culturing of cells in microfluidic chips. Thermoplastics such as polyvinyl chloride, polystyrene and high-density polyethylene are commonly used in fabrication. Moreover, the typical white color of paper makes it well suited for color-based detection methods in most assays and used for multiple bioassays in the form of origami-inspired folding devices. Elastomer is generally made up of PDMS. The glass-based microfluidic channel is made by the laser direct writing method. Thermoset, polyester-based, is a droplet-based device that can be used at different flow rates with three different oils.

\section{Application of Microfluidics in Neurodegenerative Studies}

Convergence of biology with engineering is evident in microfluidic devices used extensively nowadays in different domains of biomedical research contributing to a more powerful tool for drug delivery, point of care devices, and medical diagnostics [139]. Using microfluidics, a multichambered device can be readily prepared and used to grow neurites, glial cells, endothelial cells, and skeletal muscle cells, along with the maintenance of fluid isolation [140]. These devices can recapitulate organ-like structures and provide an opportunity to investigate organogenesis and disease etiology, accelerate drug discovery, screening, and toxicology studies by mimicking pathological conditions [141]. Utilizing hydrostatic pressure and chemical gradient profiles, localized areas of neurons grown in different compartments could be exposed to different kinds of insults applied insoluble form. A vast amount of literature exists highlighting applications of microfluidics in neurodegenerative diseases along with several neurodegenerative-disease-on-a-chip models focusing on AD, Parkinson's disease, and amyotrophic lateral sclerosis [137,138,142-145]. Furthermore, the microfluidic system has been implicated in the study of regulated cell-cell interactions, elucidating the complexity of intercellular interactions in the neuroinflammation of growing primary brain cells. 
It is well known that many brain cells interact with each other under varied conditions to cause neuroinflammation. The microfluidic devices facilitate cell culture, e.g., astrocytes in separate chambers exposed to varied situations. These chambers can be independently regulated and monitored for analyzing morphology, vitality, calcium dynamics, and electrophysiology parameters [146]. It has provided a platform to study neuronal cell death within the brain through simultaneous observation of neuronal connectivity and tau pathology [147]. Unlike 2D culture systems, these 3D cell cultures and microfluidic lab-on-a-chip technologies with in vitro microfluidics systems do not lack the mobility of the cultured cells allowing a better physiological extracellular environment, for examining, neuron-glia interactions minimizing animal morbidity and mortality [148-150]. With the help of 3D culture techniques, the discrepancies in the results of in vitro culture systems and animal models in drug discovery can be avoided [151].

Studying brain development and degeneration at the cellular level suffers several limitations due to the inability to isolate cell culture systems, the absence of an organized physiological neuron connection architecture, and so forth. In this regard, microfluidic systems present an irreplaceable tool to simulate the BBB microenvironment, study axonal functions' construction of neuronal networks, and develop drug delivery systems through devices such as axonal diodes and minimized wireless devices [22,145,152-155]. Furthermore, the technology has led to the minimization of animal models in the study of neurodegenerative diseases, drastically cutting down labor-intensive efforts, time, and animal mortality. Besides, the discrepancies that arise due to species differences between humans and animal models can also be minimized.

The lab-on-chip technologies, with features on a similar physical scale to that of cells, have facilitated the study of complex neural signaling pathways to detect abnormalities, and check whether the application of inhibitors can reverse these without the requirement of animals [156,157]. The microfluidic entities can replicate complicated cell biological processes that control synaptic function, visualize them and manipulate synaptic regions and presynaptic and postsynaptic compartments independently under in vitro conditions, and manipulate synapses and presynaptic and postsynaptic cell bodies independently [101]. Studies show that synapses lose native circuitry and order due to the dissociating of neurons for in vitro studies. The organization of cultured neurons and their connections can be improved and restored by mimicking the natural circuitry in vivo conditions through microfluidic approaches [101]. With the help of microfluidic culture devices, two distinct micro-environments can be established, which may be maintained in fluidic isolation to allow for targeted investigation and treatment.

A compartmented kind of setup to co-culture a wide variety of cells is required to understand the mechanisms of a range of neurodegenerative diseases and model neuromuscular signaling [158,159]. The microfluidic devices fulfill all these requirements and mimic the unique anatomical and cellular interactions of this circuit $[159,160]$. 3D assay systems have been developed, human brain models allowing the measurement of action potential and velocity, monitoring cell growth, drug discovery, and study of neural-glial interactions and various neurotrophic factors [156,161]. Furthermore, microfluidic neuromuscular co-culture enables innervation by axons crossing from the neuronal to the muscle compartment [162]. The same setup can be used to decipher the impact of genetic alterations on the synaptic function of CNS disorders [163]. Therefore, microfluidics applied widely in various studies of disease, including neurodegeneration. Similarly, its impact on the research and development of AD is overwhelming and promising.

\section{Impact of Microfluidic Tools in Alzheimer's Disease Research: Recent Developments}

Advancements in microfluidic technology have played a significant role in accelerating the research dedicated to the field of AD, as with other diseases, in terms of both drug discovery, exploring novel drug targets, understanding the pathophysiology, or discovering novel biomarker-based diagnostics. A list of such initiatives has been provided in Table 2. Novel AD models, which are more helpful in mimicking the complex features of 
AD pathology, have started to replace the traditional models. The 3D culture platforms are more suitable for studying AD pathophysiological mechanisms involving cell-cell interactions, controlled flow dynamics, circulating blood cells, and a brain-specific microenvironment. In a study, distinct roles of $A \beta$ on microglial accumulation have been elucidated by quantifying microglial responses in order to gain insights into the pathophysiological role of microglial migration [164].

Similarly, the effects of axonal trauma on the neuronal networks of primary brain cells and the role of astrocytes were studied on a microfluidic platform $[165,166]$. The ease, accuracy, and reproducibility of the experiments encouraged a more significant number of studies. Apart from basic research, many disposable biosensors for early detection of AD biomarker ADAM10 and A $\beta$ peptide in the serum have also been developed (limit of detection $\sim 0.35 \mathrm{fg} / \mathrm{mL}$ ) $[167,168]$. These low-cost diagnostic kits exhibit better accuracy and sensitivity than the well-established enzyme-linked immunosorbent assay test.

The emerging role of exosomes in the detection and study of AD has created the need for large-scale separation of exosomes, which is cumbersome and challenging with traditional techniques like ultra-centrifugation. Microfluidic devices are emerging as an ideal tool for exosome separation and have also started to gain recognition as excellent exosome detection tools [169]. These miniaturized platforms enable quick and cheap processing of nanovesicles even in the small volumes of liquid samples. Several microfluidic chips based on 3D neuro spheroids have been developed to mimic in vivo brain microenvironment [143]. These kinds of 3D culture-based microfluidic chip provide in vivo microenvironments for high-throughput drug screening and allow the investigation of dendrite-to-nucleus signaling [170]. Synthetic models with AD features such as aggregation of $A \beta$, and accumulation of phosphorylated tau protein with neuroinflammatory activities have been produced to emulate pathological states. A triculture in vitro model comprising the combination of neurons, astrocytes, and microglia has evolved to address the physiological features and study the durotactic behavior of cells [171]. The human AD triculture model provides an opportunity to learn about microglial recruitment, neurotoxic activities, and astrocytes [171]. A co-culture system with segregated cell bodies, while simultaneously forming myelin sheaths, could also be obtained through a microfluidics approach [172].

These studies claim to reverse the demyelination of axons which can recover the loss of sensory and motor function with the help of co-cultures. The microfluidic devices allow the study of AD-derived tau propagation from neuron to neuron. Application of microfluidic cell culture must be undergone only upon testing the cell lines with the PDMS formulations, checking for leaching of toxic compounds, and examining that the medium composition is well adjusted to suit the device and cells. Microfluidic systems present a reliable method to mimic in vivo fluid conditions of neural tissues by generating gradients to allow the diffusion of two separate fluid phases at the interface [36]. The microfluidic technology facilitates understanding of the mechanism of $A \beta$ under interstitial fluid flow conditions. These kinds of 3D culture-based microfluidic chips provide in vivo microenvironments for high-throughput drug screening [106,132]. These devices have also been used to isolate axons and the cell body to study the targets of excitotoxicity observed in neurodegeneration. In another study, the distal axon is the main target. These models can be widely used for basic mechanistic studies involved in the interaction between neural-glial cells and drug discovery. The microfluidic approach has also been used to grow a 3D human neural cell culture wherein a BBB-like phenotype was developed. The generation of such a phenotype helps in screening novel drugs capable of passing through the BBB to reach deeper neural tissues [148]. This technology facilitates the culturing of cortical neurons in two distinct cell compartments of the same microfluidic device to generate neuronal networks [173]. This setup can bring axonal degeneration in the distal axon chamber without degenerative changes in the untreated somal section [174]. Insults to the selective areas of neurons can be obtained without affecting other neurons by applying hydrostatic pressure [142]. 
Table 2. Details of microfluidic devices and their application in the AD research.

\begin{tabular}{|c|c|c|c|c|c|}
\hline Cells/Peptide & $\begin{array}{c}\text { Flow Control } \\
\text { Device }\end{array}$ & Flow Surface & Active/Passive & Application & Reference(s) \\
\hline Axon & NA & Glass & $\mathrm{P}$ & Study axonal function & [154] \\
\hline $\begin{array}{l}\text { Neural Progenitor } \\
\text { Cell }\end{array}$ & $\begin{array}{l}\text { Osmotic } \\
\text { micropump }\end{array}$ & - & A & $\begin{array}{l}\text { Study the neurotoxicity of } \\
\text { amyloid beta }\end{array}$ & [36] \\
\hline Neuron & $\begin{array}{l}\text { Osmotic } \\
\text { micropump }\end{array}$ & Glass & $A \& P$ & $\begin{array}{l}\text { in vitro brain model, } \\
\text { high-throughput drug } \\
\text { screening }\end{array}$ & [143] \\
\hline Brain Cells & $\begin{array}{l}\text { Pneumatically- } \\
\text { driven } \\
\text { pumps }\end{array}$ & Polysulfone & $\mathrm{P}$ & $\begin{array}{c}\text { To provide MPSs for in vitro } \\
\text { drug discovery }\end{array}$ & [175] \\
\hline A $\beta 42$ Peptide & Precision pump & Glass & A & $\mathrm{A} \beta(1-42)$ detection & [168] \\
\hline A $\beta$ Peptide & Syringe & - & A & - & [176] \\
\hline Axons & $\mathrm{N} / \mathrm{A}$ & Glass & $\mathrm{P}$ & Study impaired axonal deficit & [156] \\
\hline Axons & $\mathrm{N} / \mathrm{A}$ & MEA & $\mathrm{P}$ & $\begin{array}{l}\text { Investigate axonal signals in } \\
\text { developmental stage }\end{array}$ & [177] \\
\hline Neurites & Syringe & Glass & A & $\begin{array}{l}\text { Study durotactic behavior of } \\
\text { cells and neurite growth }\end{array}$ & [161] \\
\hline Axons & $\begin{array}{l}\text { Gravity/Hydrostatic } \\
\text { pressure }\end{array}$ & PCB/Glass & $P$ & $\begin{array}{l}\text { Study axonal physiology and } \\
\text { modeling CNS injury }\end{array}$ & [178] \\
\hline Soma and Axon & $\mathrm{N} / \mathrm{A}$ & Glass & $\mathrm{P}$ & $\begin{array}{l}\text { Compartmentalizing the } \\
\text { network structure } \\
\text { into interconnected } \\
\text { sub-populations }\end{array}$ & [179] \\
\hline $\begin{array}{l}\text { Hippocampal } \\
\text { Neuronal/Glia } \\
\text { Cells }\end{array}$ & Pressure gradient & Glass & $\mathrm{P}$ & $\begin{array}{c}\text { Probing the functional } \\
\text { synaptic connectivity between } \\
\text { mixed primary } \\
\text { hippocampal co-cultures }\end{array}$ & [163] \\
\hline Dendrite & $\mathrm{N} / \mathrm{A}$ & PDMS & NM & $\begin{array}{c}\text { Investigate } \\
\text { dendrite-to-nucleus signaling }\end{array}$ & [170] \\
\hline Oligodendrocyte & $\mathrm{N} / \mathrm{A}$ & Glass & $\mathrm{P}$ & - & [172] \\
\hline Drg/Mc3t3-E1 & $\mathrm{N} / \mathrm{A}$ & Glass & NM & $\begin{array}{l}\text { Mimicking the in vivo } \\
\text { scenario to study the } \\
\text { interaction between the } \\
\text { peripheral nervous system } \\
\text { and bone cells }\end{array}$ & [160] \\
\hline Nmj & Pipette & Glass & $\mathrm{N} / \mathrm{A}$ & $\begin{array}{c}\text { Study subcellular } \\
\text { microenvironments, NMJ } \\
\text { formation, maintenance, } \\
\text { and disruption }\end{array}$ & [162] \\
\hline Axons & Pipette & Glass & $\mathrm{P}$ & $\begin{array}{l}\text { Perform drug } \\
\text { screening assays }\end{array}$ & [180] \\
\hline $\begin{array}{l}\text { Dendrites and } \\
\text { Somata }\end{array}$ & Syringe & Glass & A & $\begin{array}{l}\text { Manipulate synaptic regions } \\
\text { and presynaptic and } \\
\text { postsynaptic compartments } \\
\text { in vitro }\end{array}$ & [101] \\
\hline $\begin{array}{l}\text { Glial Cells/Motor } \\
\text { Neurons }\end{array}$ & $\mathrm{N} / \mathrm{A}$ & Glass & $\mathrm{P}$ & $\begin{array}{l}\text { Study interactions with glial } \\
\text { cells and other skeletal cells in } \\
\text { the chamber }\end{array}$ & [159] \\
\hline
\end{tabular}


Table 2. Cont.

\begin{tabular}{|c|c|c|c|c|c|}
\hline Cells/Peptide & $\begin{array}{l}\text { Flow Control } \\
\text { Device }\end{array}$ & Flow Surface & Active/Passive & Application & Reference(s) \\
\hline Astrocyte & $\mathrm{N} / \mathrm{A}$ & acrylic plate & $\mathrm{P}$ & $\begin{array}{l}\text { AD triculture model showing } \\
\text { beta-amyloid aggregation, } \\
\text { phosphorylated tau } \\
\text { accumulation, and } \\
\text { neuroinflammatory activity }\end{array}$ & [144] \\
\hline Tau & $\mathrm{N} / \mathrm{A}$ & Glass & $\mathrm{P}$ & $\begin{array}{l}\text { Study effects of tau on } \\
\text { mitochondrial transport }\end{array}$ & [181] \\
\hline$(\mathrm{A} \beta)$ Peptides & $\mathrm{N} / \mathrm{A}$ & Glass & $\mathrm{P}$ & $\begin{array}{c}\text { Study effects of local A } \beta \\
\text { stress on neuronal } \\
\text { sub-compartments and } \\
\text { networks }\end{array}$ & [182] \\
\hline ADAM10 & Syringe & $\mathrm{N} / \mathrm{A}$ & $\mathrm{A}$ & $\begin{array}{l}\text { ADAM10 biomarker detection } \\
\text { in plasma and } \\
\text { cerebrospinal fluid }\end{array}$ & [167] \\
\hline Tau & $\mathrm{N} / \mathrm{A}$ & Glass & $\mathrm{P}$ & $\begin{array}{l}\text { Quantify AD-derived } \\
\text { Tau propagation }\end{array}$ & [147] \\
\hline $\mathrm{A} \beta$ & $\mathrm{N} / \mathrm{A}$ & Glass & $\mathrm{P}$ & $\begin{array}{l}\text { Study roles of } A \beta \text { on } \\
\text { microglial accumulation }\end{array}$ & [183] \\
\hline $\mathrm{A} \beta$ & Syringe & $\begin{array}{l}\text { Overflow } \\
\text { microfluidic } \\
\text { networks }\end{array}$ & $\mathrm{A}$ & $\begin{array}{c}\text { Study cell-to-cell } \\
\text { communication, role of } \\
\text { astrocytes derived from cortex } \\
\text { and hippocampus on } \\
\text { neuronal viability }\end{array}$ & [146] \\
\hline Axons & - & Glass & - & $\begin{array}{l}\text { Study mechanisms of indirect } \\
\text { axonal excitotoxicity }\end{array}$ & [174] \\
\hline Neurites & $\begin{array}{l}\text { Hydrostatic } \\
\text { pressure }\end{array}$ & $\begin{array}{l}\text { Glass and } \\
\text { Polystyrene }\end{array}$ & $\mathrm{P}$ & Grow neuronal culture & [142] \\
\hline Cortical Neurons & Pressure difference & Glass & $\mathrm{P}$ & $\begin{array}{l}\text { Synthesize experimental } \\
\text { models emulating } \\
\text { pathological states }\end{array}$ & [173] \\
\hline $\begin{array}{l}\text { Ren-WT/Ren-AD } \\
\text { Cells }\end{array}$ & $\mathrm{N} / \mathrm{A}$ & Glass & $\mathrm{P}$ & $\begin{array}{l}\text { Grow 3D human neural cell } \\
\text { culture, screen novel drugs } \\
\text { capable of passing through } \\
\text { the BBB to reach deeper } \\
\text { neural tissues }\end{array}$ & [148] \\
\hline Protein & $\mathrm{N} / \mathrm{A}$ & Glass & $\mathrm{P}$ & Detect protein aggregation & [184] \\
\hline Axons & $\begin{array}{l}\text { Hydrostatic } \\
\text { pressure }\end{array}$ & $\begin{array}{c}\text { Glass or } \\
\text { Polystyrene }\end{array}$ & $\mathrm{P}$ & $\begin{array}{l}\text { Study localized axon-glia } \\
\text { interaction and signaling }\end{array}$ & [185] \\
\hline Axons & $\mathrm{N} / \mathrm{A}$ & Glass & $\mathrm{P}$ & $\begin{array}{l}\text { Examine axonal trauma in } \\
\text { neuronal networks }\end{array}$ & [166] \\
\hline Axons-glia & $\begin{array}{l}\text { Hydrostatic } \\
\text { pressure }\end{array}$ & Glass & $\mathrm{P}$ & Study axon-glia interactions & [186] \\
\hline Neurites & Syringe & Glass & A & $\begin{array}{c}\text { Investigating chemotaxis } \\
\text { of neutrophils }\end{array}$ & [187] \\
\hline
\end{tabular}

Abbreviations: MPSs, Micro-physiological systems; DRG, Dorsal root ganglion; NMJ, Neuromuscular junction; MEA, Microelectrode arrays.

8. Challenges in the Application of Microfluidics in the Alzheimer's Disease Research

Although microfluidics provides a state-of-the-art facility that enables investigations in biomedical research, there are many challenges that need to be addressed before the optimal utilization of this field's potential. Experts believe that the area of microfluidics 
research needs to grow further in order to outperform existing laboratory methods and overcome barriers that hinder researchers from adopting microfluidic-based devices as a common research tool.

First of all, the lack of precise fluid handling techniques at such a microscopic level poses great difficulty in attaining the exact quantity of reagents for performing molecular experiments. Though achieved once, it becomes difficult to replicate the experiments with acceptable accuracy. The second major problem is that it is difficult to scale up the experiments under the same experimental conditions with the same volume of reagents. This is because of inability in fluid handling and duplicating culture or reaction conditions. Often cells may respond differently toa change in the substrate of microfluidic devices. Thirdly, the majority of the culture protocols have been optimized on polystyrene culture plates, a significant component in macroscale devices, unlike microfluidic cell culture devices that use PDMS. New production techniques favoring mass production such as microfluidic hot embossing in polystyrene have been found useful in minimizing the risk of translation failure in microfluidic devices, yet PDMS is the most commonly used substrate for fabricating these devices [188].

Any variation in the reagent volume or reaction conditions leads to inaccurate results and protocols. Moreover, a direct comparison with the macroscale experiments become very difficult as a change in the substrate may hinder the transition of the protocols to the microscale levels. Studies indicate that PDMS may absorb or adsorb the biomolecules from the medium, causing biased experimental conditions [189,190]. Absorption and/or adsorption of reagents will alter the reaction volumes, which is another demerit that microfluidic devices currently face. In addition, we do not know whether PDMS, a material known for its transparency and gas permeability, has any impact on cellular behavior. Since it is the material of choice at present, ascertaining its effect on cellular behavior is essential.

Excessive permeability, technical robustness, and other properties might lead to sample drying and change in osmolarity, posing a considerable obstruction. Samples collected on chips/microfluidic channels for analysis using chip-based PCR, histochemistry, western blots, or MS-Spectrometry will fail to give accurate results upon a slight change in the volume of reaction constituents $[104,191]$. Additionally, these experiments require the reagents to be properly mixed, but microfluidics produces slow diffusive mixing due to laminar flows, posing a major limitation for these systems wherein fast homogenization is required [192].

The lack of a universal blood substitute or standard culture media that supports all types of tissue is an additional setback. Other drawbacks that must be addressed in the future for the optimal application of microfluidics in Alzheimer's research is its interdisciplinary nature, wherein standardized protocols are generally absent. A combined effort of engineers and molecular biologists is required to fabricate new device designs and carry out biologically relevant experiments [36]. As a range of cell lines are cultured in these devices, generalization in device designs is difficult.

It is well known that physical parameters such as flow, pressure, temperature, $\mathrm{pH}$, and real-time monitoring are equally important in carrying out biological experiments with accuracy. To ascertain these parameters, newly designed chips are now well integrated with the in-line sensors and microfluorimetric imaging facilities, but the chip still lacks features such as feedback control, continuous monitoring, and experimental sample processing. Unlike macroscopic laboratory practices, an automated control system is required to expand the domain of users and replace the 2D or 3D culture systems. The 3D tri culture AD model is gaining popularity as it is undoubtedly advanced over in vitro human AD models. Nonetheless, physiologically relevant in vivo studies are still required to confirm its clinical utility [144].

\section{Conclusions}

Even after a century of extensive research, the field of $\mathrm{AD}$ requires more work in the appropriate direction to come up with effective diagnostics and therapeutic cures $[12,56,193]$. 
The crucial research problems are challenging with current macroscopic laboratory equipment and practices. The research is at a crossroads where rigor is required to determine the right direction and appropriate focus. Microfluidic systems facilitate work on functional organs at the level of molecular analysis, significantly minimizing the complications involved in handling in vivo systems. These devices outperform age-old methodologies through features such as rapid sample processing, fluid control, flexibility of design, controlled co-culture, reduced reagent consumption, low contamination risk, and efficient high throughput experimentation. Undoubtedly, these novel neurotechnological tools are very useful in gaining an in-depth understanding of the brain's functions and discovering novel therapeutic strategies for neurological disorders like AD. However, the extent to which this technology can serve in AD detection and management is still in a nascent phase. This is because the technology has not been developed to recapitulate biological responses to various stimuli such as chemicals or toxins. Although organs-on-chips may lead to the identification of biomarkers and validation of lead drug candidates, clinically relevant PK/PD models are required to determine the drug doses. In this regard, better scaling approaches to keep an account of fluid flows and volumes of distribution would ensure functional PK/PD models. It is doubtful that organs-on-chips will replace animal testing anytime soon, as the organ function and regulatory requirements are highly complex. Nonetheless, these low-cost techniques are up-and-coming and have accelerated the pace of $\mathrm{AD}$ research.

Author Contributions: Conceptualization, supervision, writing—original draft preparation, data curation; Reviewing and editing, P.P.; Visualization, S.R.; Data curation, writing—original draft preparation; visualization, V.R.; Reviewing and editing, D.M.; Reviewing and editing, M.S.C.G.; Reviewing and editing, P.Y.; Reviewing and editing, S.H.; Reviewing and editing, A.S.; Reviewing and editing, P.K.G.; Reviewing and editing, S.O.; Artwork and schemes, N.K.J.; Reviewing and editing, C.V.; Conceptualization, supervision, writing-original draft preparation, data curation; Reviewing and editing, S.K.J. All authors have read and agreed to the published version of the manuscript.

Funding: The present work did not receive any specific grant from funding agencies in the public, commercial, or not-for-profit sectors.

Institutional Review Board Statement: Not Applicable.

Informed Consent Statement: Not Applicable.

Data Availability Statement: Not Applicable.

Conflicts of Interest: The authors have no conflict of interest to declare.

\section{Abbreviations}

AD Alzheimer's disease

ADAM10 A Disintegrin and Metalloprotease 10

Apo E Apolipoprotein E

A $\beta \quad$ Amyloid-beta

CD33 Complementary determinant 33

IL Interleukin

MMP Matrix metallopeptidase 9

NMJ Neuromuscular junction

PCR Polymerase chain reaction

PDMS Polydimethylsiloxane

PK/PD Pharmacokinetic/Pharmacodynamic

TNF- $\alpha \quad$ Tumor necrosis factor-alpha

TREM2 Triggering receptor expressed on myeloid cells2 


\section{References}

1. Jha, N.K.; Jha, S.K.; Kar, R.; Nand, P.; Swati, K.; Goswami, V.K. Nuclear factor-kappa $\beta$ as a therapeutic target for Alzheimer's disease. J. Neurochem. 2019, 150, 113-137. [CrossRef]

2. Crimins, J.L.; Pooler, A.; Polydoro, M.; Luebke, J.I.; Spires-Jones, T.L. The Intersection of Amyloid Beta and Tau in Glutamatergic Synaptic Dysfunction and Collapse in Alzheimer's Disease. Ageing Res. Rev. 2013, 12, 757-763. [CrossRef]

3. Kumar, P.; Jha, N.K.; Jha, S.K.; Ramani, K.; Ambasta, R.K. Tau phosphorylation, molecular chaperones, and ubiquitin E3 ligase: Clinical relevance in Alzheimer's disease. J. Alzheimers Dis. 2015, 43, 341-461. [CrossRef]

4. Lee, J.C.; Kim, S.J.; Hong, S.; Kim, Y.S. Diagnosis of Alzheimer's Disease Utilizing Amyloid and Tau as Fluid Biomarkers. Exp. Mol. Med. 2019, 51, 1-10. [CrossRef] [PubMed]

5. Jha, S.K.; Jha, N.K.; Kumar, D.; Sharma, R.; Shrivastava, A.; Ambasta, R.K.; Kumar, P. Stress-Induced Synaptic Dysfunction and Neurotransmitter Release in Alzheimer's Disease: Can Neurotransmitters and Neuromodulators be Potential Therapeutic Targets? J. Alzheimers Dis. 2017, 57, 1017-1039. [CrossRef] [PubMed]

6. Jha, N.K.; Jha, S.K.; Kumar, D.; Kejriwal, N.; Sharma, R.; Ambasta, R.K.; Kumar, P. Impact of Insulin Degrading Enzyme and Neprilysin in Alzheimer's Disease Biology: Characterization of Putative Cognates for Therapeutic Applications. J. Alzheimers Dis. 2015, 48, 891-917. [CrossRef]

7. Liu, C.-C.; Kanekiuo, T.; Xu, H.; Bu, G. Apolipoprotein E and Alzheimer Disease: Risk, Mechanisms and Therapy. Nat. Rev. Neurol. 2013, 9, 106-118. [CrossRef]

8. D'Argenio, V.; Sarnataro, D. New Insights into the Molecular Bases of Familial Alzheimer's Disease. J. Pers. Med. 2020, 10, 26. [CrossRef]

9. Lynch, C. World Alzheimer Report 2019: Attitudes to Dementia, a Global Survey. Alzheimers Dement. 2020, 16, e038255. [CrossRef]

10. 2021 Alzheimer's Disease Facts and Figures. Alzheimers Dement. 2021, 17, 327-406. [CrossRef]

11. International, D. World Alzheimer Report 2020-Design Dignity Dementia: Dementia-Related Design and the Built Environment. Alzheimers Dis. Int. 2020, 1, 106-113.

12. Holtzman, D.M.; Morris, J.C.; Goate, A.M. Alzheimer's Disease: The Challenge of the Second Century. Sci. Transl. Med. 2011, 3, 77. [CrossRef] [PubMed]

13. Kocahan, S.; Doğan, Z. Mechanisms of Alzheimer's Disease Pathogenesis and Prevention: The Brain, Neural Pathology, NMethyl-D-Aspartate Receptors, Tau Protein and Other Risk Factors. Clin. Psychopharmacol. Neurosci. 2017, 15, 1-8. [CrossRef]

14. Yiannopoulou, K.G.; Papageorgiou, S.G. Current and Future Treatments for Alzheimer's Disease. Ther. Adv. Neurol. Disord. 2013, 6, 19. [CrossRef]

15. Guo, T.; Zhang, D.; Zeng, Y.; Huang, T.Y.; Xu, H.; Zhao, Y. Molecular and Cellular Mechanisms Underlying the Pathogenesis of Alzheimer's Disease. Mol. Neurodegener. 2020, 15, 1-37. [CrossRef] [PubMed]

16. Strassnig, M.; Ganguli, M. About a Peculiar Disease of the Cerebral Cortex: Alzheimer's Original Case Revisited. Psychiatry 2005, 2, 30-33. [PubMed]

17. You, Y.; Perkins, A.; Cisternas, P.; Muñoz, B.; Taylor, X.; You, Y.; Garringer, H.J.; Oblak, A.L.; Atwood, B.K.; Vidal, R.; et al. Tau as a Mediator of Neurotoxicity Associated to Cerebral Amyloid Angiopathy. Acta Neuropathol. Commun. 2019, 7, 26. [CrossRef] [PubMed]

18. Huang, H.C.; Jiang, Z.F. Accumulated Amyloid- $\beta$ Peptide and Hyperphosphorylated Tau Protein: Relationship and Links in Alzheimer's Disease. J. Alzheimers Dis. 2009, 16, 15-27. [CrossRef]

19. Li, Y.; Li, D.; Zhao, P.; Nandakumar, K.; Wang, L.; Song, Y. Microfluidics-Based Systems in Diagnosis of Alzheimer's Disease and Biomimetic Modeling. Micromachines 2020, 11, 787. [CrossRef]

20. Velve-Casquillas, G.; Le Berre, M.; Piel, M.; Tran, P.T. Microfluidic Tools for Cell Biological Research. Nano Today 2010, 5, $28-47$. [CrossRef]

21. Edmondson, R.; Broglie, J.J.; Adcock, A.F.; Yang, L. Three-Dimensional Cell Culture Systems and Their Applications in Drug Discovery and Cell-Based Biosensors. ASSAY Drug Dev. Technol. 2014, 12, 207-218. [CrossRef] [PubMed]

22. Lam, D.; Enright, H.A.; Cadena, J.; Peters, S.K.; Sales, A.P.; Osburn, J.J.; Soscia, D.A.; Kulp, K.S.; Wheeler, E.K.; Fischer, N.O. Tissue-specific extracellular matrix accelerates the formation of neural networks and communities in a neuron-glia co-culture on a multi-electrode array. Sci. Rep. 2019, 9, 1-5.

23. Goedert, M.; Spillantini, M.G. A Century of Alzheimer's Disease. Science 2006, 314, 777-781. [CrossRef] [PubMed]

24. Deture, M.A.; Dickson, D.W. The Neuropathological Diagnosis of Alzheimer's Disease. Mol. Neurodegener. 2019, 14, 32. [CrossRef]

25. Li, H.; Liu, C.C.; Zheng, H.; Huang, T.Y. Amyloid, Tau, Pathogen Infection and Antimicrobial Protection in Alzheimer's Disease -Conformist, Nonconformist, and Realistic Prospects for AD Pathogenesis. Transl. Neurodegener. 2018, 7, 34. [CrossRef]

26. De-Paula, V.J.; Radanovic, M.; Diniz, B.S.; Forlenza, O.V. Alzheimer's Disease. Subcell. Biochem. 2012, 65, 329-352.

27. Jack, C.R., Jr.; Holtzman, D.M. Biomarker modeling of Alzheimer's disease. Neuron 2013, 80, 1347-1358. [CrossRef]

28. Sinha, S.M.; Ansell-Schultz, A.; Civitelli, L.; Hildesjö, C.; Larsson, M.; Lannfelt, L.; Ingelsson, M.; Hallbeck, M. Alzheimer's Disease Pathology Propagation by Exosomes Containing Toxic Amyloid-Beta Oligomers. Acta Neuropathol. 2018, 136, 41-56. [CrossRef]

29. Murphy, M.P.; LeVine, H., III. Alzheimer's Disease and the $\$ \beta \$$-Amyloid Peptide. J. Alzheimers Dis. 2010, 19, 311. [CrossRef]

30. Sengupta, U.; Nilson, A.N.; Kayed, R. The Role of Amyloid- $\beta$ Oligomers in Toxicity, Propagation, and Immunotherapy. EBioMedicine 2016, 6, 42-49. [CrossRef] 
31. Tanzi, R.E.; Bertram, L. Twenty Years of the Alzheimer's Disease Amyloid Hypothesis: A Genetic Perspective. Cell 2005, 120, 545-555. [CrossRef] [PubMed]

32. Chen, X.Q.; Mobley, W.C. Exploring the Pathogenesis of Alzheimer Disease in Basal Forebrain Cholinergic Neurons:Converging Insights from Alternative Hypotheses. Front. Neurosci. 2019, 13, 446. [CrossRef] [PubMed]

33. Brenowitz, W.D.; Nelson, P.T.; Besser, L.M.; Heller, K.B.; Kukull, W.A. Cerebral Amyloid Angiopathy and Its Co-Occurrence with Alzheimer's Disease and Other Cerebrovascular Neuropathologic Changes. Neurobiol. Aging 2015, 36, 2702-2708. [CrossRef]

34. Hansen, D.V.; Hanson, J.E.; Sheng, M. Microglia in Alzheimer's Disease. J. Cell Biol. 2018, 217, 459-472. [CrossRef] [PubMed]

35. Mandrekar-Colucci, S.; Landreth, G.E. Microglia and Inflammation in Alzheimers Disease. CNS Neurol Disord. Drug Targets 2012, 9, 156-167. [CrossRef] [PubMed]

36. Choi, Y.J.; Chae, S.; Kim, J.H.; Barald, K.F.; Park, J.Y.; Lee, S.H. Neurotoxic Amyloid Beta Oligomeric Assemblies Recreated in Microfluidic Platform with Interstitial Level of Slow Flow. Sci. Rep. 2013, 3, 1921. [CrossRef]

37. Wang, W.-Y.; Tan, M.-S.; Yu, J.T.; Tan, L. Role of Pro-Inflammatory Cytokines Released from Microglia in Alzheimer's Disease. Ann. Transl. Med. 2015, 3, 136.

38. Ismail, R.; Parbo, P.; Madsen, L.S.; Hansen, A.K.; Hansen, K.V.; Schaldemose, J.L.; Kjeldsen, P.L.; Stokholm, M.G.; Gottrup, M.G.; Eskildsen, S.F.; et al. The Relationships between Neuroinflammation, Beta-Amyloid and Tau Deposition in Alzheimer's Disease: A Longitudinal PET Study. J. Neuroinflammation 2020, 17, 151. [CrossRef]

39. Ardura-Fabregat, A.; Boddeke, E.W.G.M.; Boza-Serrano, A.; Brioschi, S.; Castro-Gomez, S.; Ceyzeriat, K.; Dansokho, C.; Dierkes, T.; Gelders, G.; Heneka, M.T.; et al. Targeting Neuroinflammation to Treat Alzheimer's Disease. CNS Drugs 2017, 31, 1057-1082. [CrossRef]

40. Yamazaki, Y.; Kanekiyo, T. Blood-Brain Barrier Dysfunction and the Pathogenesis of Alzheimer's Disease. Int. J. Mol. Sci. 2017, 18, 1956. [CrossRef]

41. Sweeney, M.D.; Sagare, A.P.; Zlokovic, B.V. Blood-Brain Barrier Breakdown in Alzheimer Disease and Other Neurodegenerative Disorders. Nat. Rev. Neurol. 2018, 14, 133-150. [CrossRef] [PubMed]

42. Calsolaro, V.; Edison, P. Neuroinflammation in Alzheimer's Disease: Current Evidence and Future Directions. Alzheimers Dement. 2016, 12, 719-732. [CrossRef] [PubMed]

43. Rempe, R.G.; Hartz, A.M.S.; Bauer, B. Matrix Metalloproteinases in the Brain and Blood-Brain Barrier: Versatile Breakers and Makers. Br. J. Pharmacol. 2016, 36, 1481. [CrossRef] [PubMed]

44. Fernandez, C.G.; Hamby, M.E.; McReynolds, M.L.; Ray, W.J. The Role of APOE4 in Disrupting the Homeostatic Functions of Astrocytes and Microglia in Aging and Alzheimer's Disease. Front. Aging Neurosci. 2019, 11, 14. [CrossRef]

45. Bird, T.D. Genetic Aspects of Alzheimer Disease. Genet. Med. 2009, 10, 231-239. [CrossRef]

46. Birks, J.S.; Chong, L.Y.; Evans, J.G. Rivastigmine for Alzheimer's Disease. Cochrane Database Syst. Rev. 2015,9 , CD001191.

47. Woodruff-Pak, D.S.; Vogel, R.W.; Wenk, G.L. Galantamine: Effect on Nicotinic Receptor Binding, Acetylcholinesterase Inhibition, and Learning. Proc. Natl. Acad. Sci. USA 2001, 98, 2089-2094. [CrossRef]

48. Lilienfeld, S. Cholinesterase Inhibitors for Alzheimer Disease. JAMA 2003, 289, 2359. [CrossRef]

49. Govind, N. Donepezil for Dementia Due to Alzheimer's Disease. Br. J. Community Nurs. 2020, 25, 148-149. [CrossRef] [PubMed]

50. Casey, D.A.; Antimisiaris, D.; O'Brien, J. Drugs for Alzheimer's Disease: Are They Effective? Pharm. Ther. 2010, 35, $208-211$.

51. Villa, C. Biomarkers for Alzheimer's Disease: Where Do We Stand and Where Are We Going? J. Pers. Med. 2020, 10, 238. [CrossRef]

52. Ray, S.; Britschgi, M.; Herbert, C.; Takeda-Uchimura, Y.; Boxer, A.; Blennow, K.; Friedman, L.F.; Galasko, D.R.; Jutel, M.; Karydas, A.; et al. Classification and Prediction of Clinical Alzheimer's Diagnosis Based on Plasma Signaling Proteins. Nat. Med. 2007, 13, 1359-1362. [CrossRef] [PubMed]

53. O'Bryant, S.E.; Xiao, G.; Barber, R.; Reisch, J.; Hall, J.; Cullum, C.M.; Doody, R.; Fairchild, T.; Adams, P.; Wilhelmsen, K.; et al. A Blood-Based Algorithm for the Detection of Alzheimer's Disease. Dement. Geriatr. Cogn. Disord. 2011, 32, 55-62. [CrossRef] [PubMed]

54. Galimberti, D.; Villa, C.; Fengolio, C.; Serpente, M.; Ghezzi, L.; Cioffi, S.M.G.; Arighi, A.; Fumagalli, G.; Scrapini, E. Circulating MiRNAs as Potential Biomarkers in Alzheimer's Disease. J. Alzheimers Dis. 2014, 42, 1261-1267. [CrossRef] [PubMed]

55. Wisniewski, T.; Konietzko, U. Amyloid- $\beta$ Immunisation for Alzheimer's Disease. Lancet Neurol. 2008, 7, 805. [CrossRef]

56. Ricciarelli, R.; Fedele, E. The Amyloid Cascade Hypothesis in Alzheimer's Disease: It's Time to Change Our Mind. Curr. Neuropharmacol. 2017, 15, 926-935. [CrossRef]

57. Wu, Y.Y.; Cheng, I.H.; Lee, C.C.; Chiu, M.J.; Lee, M.J.; Chen, T.F.; Hsu, J.L. Clinical phenotype of G206D mutation in the presenilin 1 gene in pathologically confirmed familial Alzheimer's disease. J. Alzheimers Dis. 2011, 25, 145-150. [CrossRef]

58. Liu, P.P.; Xie, Y.; Meng, X.Y.; Kang, J.S. History and Progress of Hypotheses and Clinical Trials for Alzheimer's Disease. Signal Transduct. Target. Ther. 2019, 4, 1-22.

59. Takeda, S. Tau Propagation as a Diagnostic and Therapeutic Target for Dementia: Potentials and Unanswered Questions. Front. Neurosci. 2019, 13, 1274. [CrossRef]

60. Ballatore, C.; Lee, V.M.Y.; Trojanowski, J.Q. Tau-Mediated Neurodegeneration in Alzheimer's Disease and Related Disorders. Nat. Rev. Neurosci. 2007, 8, 663-672. [CrossRef]

61. Marshall, K.E.; Vadukul, D.M.; Dahal, L.; Theisen, A.; Fowler, M.W.; Al-Hilaly, Y.; Ford, L.; Kemenes, G.; Day, I.J.; Staras, K.; et al. A Critical Role for the Self-Assembly of Amyloid-B1-42 in Neurodegeneration. Sci. Rep. 2016, 6, 30182. [CrossRef] [PubMed] 
62. Broersen, K.; Rousseau, F.; Schymkowitz, J. The Culprit behind Amyloid Beta Peptide Related Neurotoxicity in Alzheimer's Disease: Oligomer Size or Conformation? Alzheimers Res. Ther. 2010, 2, 12. [CrossRef] [PubMed]

63. Rabbito, A.; Dulewicz, M.; Kulczyńska-Przybik, A.; Mroczko, B. Biochemical Markers in Alzheimer's Disease. Int. J. Mol. Sci. 2020, 21, 1989. [CrossRef]

64. O’Bryant, S.E.; Mielke, M.M.; Rissman, R.A.; Lista, S.; Vanderstichele, H.; Zetterberg, H.; Lewczuk, P.; Posner, H.; Hall, J.; Johnson, L.; et al. Blood-Based Biomarkers in Alzheimer Disease: Current State of the Science and a Novel Collaborative Paradigm for Advancing from Discovery to Clinic. Alzheimers Dement. 2017, 13, 45-58. [CrossRef] [PubMed]

65. Kwon, H.S.; Koh, S.-H. Neuroinflammation in Neurodegenerative Disorders: The Roles of Microglia and Astrocytes. Transl. Neurodegener. 2020, 9, 42. [CrossRef] [PubMed]

66. Dawson, T.M.; Golde, T.E.; Lagier-Tourenne, C. Animal Models of Neurodegenerative Diseases. Nat. Neurosci. 2018, 21, 1370-1379. [CrossRef] [PubMed]

67. Zhang, Y.; Liu, Y.; Liu, H.; Tang, W.H. Exosomes: Biogenesis, Biologic Function and Clinical Potential. Cell Biosci. 2019, 9, 19. [CrossRef]

68. Yin, Q.; Ji, X.; Lv, R.; Pei, J.J.; Du, Y.; Shen, C.; Hou, X. Targetting Exosomes as a New Biomarker and Therapeutic Approach for Alzheimer's Disease. Clin. Interv. Aging 2020, 15, 195-205. [CrossRef]

69. Howitt, J.; Hill, A.F. Exosomes in the Pathology of Neurodegenerative Diseases. J. Biol. Chem. 2016, 291, 26589-26597. [CrossRef]

70. Thompson, A.G.; Gray, E.; Heman-Ackah, S.M.; Mäger, I.; Talbot, K.; El Andaloussi, S.; Wood, M.J.; Turner, M.R. Extracellular Vesicles in Neurodegenerative Disease-Pathogenesis to Biomarkers. Nat. Rev. Neurol. 2016, 12, 346-357. [CrossRef]

71. Saraceno, C.; Musardo, S.; Marcello, E.; Pelucchi, S.; Luca, M.D. Modeling Alzheimer's Disease: From Past to Future. Front. Pharmacol. 2013, 4, 77. [CrossRef]

72. Grolla, A.A.; Sim, J.A.; Lim, D.; Rodriguez, J.J.; Genazzani, A.A.; Verkhratsky, A. Amyloid- $\beta$ and Alzheimer's Disease Type Pathology Differentially Affects the Calcium Signalling Toolkit in Astrocytes from Different Brain Regions. Cell Death Dis. 2013, 4, e623. [CrossRef]

73. Krabbe, G.; Halle, A.; Matyash, V.; Rinnenthal, J.L.; Eom, G.D.; Bernhardt, U.; Miller, K.R.; Prokop, S.; Kettenmann, H.; Heppner, F.L. Functional Impairment of Microglia Coincides with Beta-Amyloid Deposition in Mice with Alzheimer-like Pathology. PLoS ONE 2013, 8, e60921. [CrossRef]

74. Nguyen, T.L.X.; Kim, C.K.; Cho, J.-H.; Lee, K.-H.; Ahn, J.-Y. Neuroprotection Signaling Pathway of Nerve Growth Factor and Brain-Derived Neurotrophic Factor against Staurosporine Induced Apoptosis in Hippocampal H19-7/IGF-IR [Corrected]. Exp. Mol. Med. 2010, 42, 583-595. [CrossRef] [PubMed]

75. Medeiros, L.M.D.; Bastiani, M.A.D.; Rico, E.P.; Schonhofen, P.; Pfaffenseller, B.; Wollenhaupt-Aguiar, B.; Grun, L.; Barbe-Tuana, F.; Zimmer, E.R.; Castro, M.A.A.; et al. Cholinergic Differentiation of Human Neuroblastoma SH-SY5Y Cell Line and Its Potential Use as an In vitro Model for Alzheimer's Disease Studies. Mol. Neurobiol. 2019, 56, 7355-7367. [CrossRef] [PubMed]

76. Zhang, L.; Yu, H.; Zhao, X.; Lin, X.; Tan, C.; Cao, G.; Wang, Z. Neuroprotective Effects of Salidroside against Beta-Amyloid-Induced Oxidative Stress in SH-SY5Y Human Neuroblastoma Cells. Neurochem. Int. 2010, 57, 547-555. [CrossRef] [PubMed]

77. Forster, J.I.; Koglsberger, S.; Trefois, C.; Boyd, O.; Baumuratov, A.S.; Buck, L.; Balling, R.; Antony, P.M.A. Characterization of Differentiated SH-SY5Y as Neuronal Screening Model Reveals Increased Oxidative Vulnerability. J. Biomol. Screen. 2016, 21, 496-509. [CrossRef]

78. Song, G.; Li, Y.; Lin, L.; Cao, Y. Anti-Autophagic and Anti-Apoptotic Effects of Memantine in a SH-SY5Y Cell Model of Alzheimer's Disease via Mammalian Target of Rapamycin-Dependent and -Independent Pathways. Mol. Med. Rep. 2015, 12, 7615-7622. [CrossRef]

79. Dafnis, I.; Argyri, L.; Sagnou, M.; Tzinia, A.; Tsilibary, E.C.; Stratikos, E.; Chroni, A. The Ability of Apolipoprotein E Fragments to Promote Intraneuronal Accumulation of Amyloid Beta Peptide 42 Is Both Isoform and Size-Specific. Sci. Rep. 2016, 6, 30654. [CrossRef]

80. Yagi, T.; Ito, D.; Okada, Y.; Akamatsu, W.; Nihei, Y.; Yoshizaki, T.; Yamanaka, S.; Okano, H.; Suzuki, N. Modeling Familial Alzheimer's Disease with Induced Pluripotent Stem Cells. Hum. Mol. Genet. 2011, 20, 4530-4539. [CrossRef]

81. Muratore, C.R.; Rice, H.C.; Srikanth, P.; Callahan, D.G.; Shin, T.; Benjamin, L.N.P.; Walsh, D.M.; Selkoe, D.J.; Young-Pearse, T. The Familial Alzheimer's Disease APPV717I Mutation Alters APP Processing and Tau Expression in IPSC-Derived Neurons. Hum. Mol. Genet. 2014, 23, 3523-3536. [CrossRef]

82. Kondo, T.; Asai, M.; Tsukita, K.; Kutoku, Y.; Ohsawa, Y.; Sunda, Y.; Imamura, K.; Egawa, N.; Yahata, N.; Okita, K.; et al. Modeling Alzheimer's Disease with IPSCs Reveals Stress Phenotypes Associated with Intracellular A $\beta$ and Differential Drug Responsiveness. Cell Stem Cell 2013, 12, 487-496. [CrossRef]

83. Israel, M.A.; Yuan, S.H.; Bardy, C.; Reyna, S.M.; Mu, Y.; Herrera, C.; Hefferan, M.P.; Gorp, S.V.; Nazor, K.L.; Boscolo, F.S.; et al. Probing Sporadic and Familial Alzheimer's Disease Using Induced Pluripotent Stem Cells. Nature 2012, 482, 216-220. [CrossRef]

84. Jones, V.C.; Atkinson, R.-D.; Verkharatsky, A.; Mohamet, L. Aberrant IPSC-Derived Human Astrocytes in Alzheimer's Disease. Cell Death Dis. 2017, 8, e2696. [CrossRef]

85. Lin, Y.-T.; Seo, J.; Gao, F.; Feldman, H.M.; Wen, H.-L.; Penney, J.; Cam, H.P.; Gjoneska, E.; Raja, W.K.; Cheng, J.; et al. APOE4 Causes Widespread Molecular and Cellular Alterations Associated with Alzheimer's Disease Phenotypes in Human IPSC-Derived Brain Cell Types. Neuron 2018, 98, 1141-1154. [CrossRef] [PubMed] 
86. Gerakis, Y.; Hetz, C. Brain Organoids: A next Step for Humanized Alzheimer's Disease Models? Mol. Psychiatry 2019, 24, 474-478. [CrossRef] [PubMed]

87. Zeng, X.; Hunsberger, J.G.; Simeonov, A.; Malik, N.; Pei, Y.; Rao, M. Concise review: Modeling central nervous system diseases using induced pluripotent stem cells. Stem Cells Transl. Med. 2014, 3, 1418-1428. [CrossRef] [PubMed]

88. Li, X.; Bao, X.; Wang, R. Experimental Models of Alzheimer's Disease for Deciphering the Pathogenesis and Therapeutic Screening (Review). Int. J. Mol. Med. 2016, 37, 271-283. [CrossRef] [PubMed]

89. Oddo, S.; Caccamo, A.; Shepherd, J.D.; Murphy, M.P.; Golde, T.E.; Kayed, R.; Metherate, R.; Mattson, M.P.; Akbari, Y.; LaFerla, F.M. Triple-Transgenic Model of Alzheimer's Disease with Plaques and Tangles: Intracellular Abeta and Synaptic Dysfunction. Neuron 2003, 39, 409-421. [CrossRef]

90. Oakley, H.; Cole, S.L.; Logan, S.; Maus, E.; Shao, P.; Craft, J.; Guillozet, A.-B.; Ohno, M.; Disterhoft, J.; Eldik, L.V.; et al. Intraneuronal Beta-Amyloid Aggregates, Neurodegeneration, and Neuron Loss in Transgenic Mice with Five Familial Alzheimer's Disease Mutations: Potential Factors in Amyloid Plaque Formation. J. Neurosci. 2006, 26, 10129-10140. [CrossRef]

91. Grootendorst, J.; Bour, A.; Vogel, E.; Kelche, C.; Sullivan, P.M.; Dodart, J.-C.; Bales, K.; Mathis, C. Human ApoE Targeted Replacement Mouse Lines: H-ApoE4 and h-ApoE3 Mice Differ on Spatial Memory Performance and Avoidance Behavior. Behav. Brain Res. 2005, 159, 1-14. [CrossRef]

92. Shi, Y.; Yamada, K.; Liddelow, S.A.; Smith, S.T.; Zhao, L.; Luo, W.; Tsai, R.M.; Spina, S.; Grinberg, L.T.; Rojas, J.C.; et al. ApoE4 Markedly Exacerbates Tau-Mediated Neurodegeneration in a Mouse Model of Tauopathy. Nature 2017, 549, 523-527. [CrossRef]

93. Bales, K.R.; Liu, F.; Wu, S.; Lin, S.; Koger, D.; DeLong, C.; Hansen, J.C.; Sullivan, P.M.; Paul, S.M. Human APOE Isoform-Dependent Effects on Brain $\beta$-Amyloid Levels in PDAPP Transgenic Mice. J. Neurosci. 2009, 29, 6771-6779. [CrossRef]

94. Flores, J.A.-C.; Madrid, A.; Fernandez, P.L.; Perez, A.R.-L.; Oviedo, D.C.; Britton, G.B.; Carreira, M. Critical Review of the Alzheimer's Disease Non-Transgenic Models: Can They Contribute to Disease Treatment? J. Alzheimers Dis. 2021, 82, S227-S250. [CrossRef] [PubMed]

95. Liu, B.; Liu, J.; Shi, J.-S. SAMP8 Mice as a Model of Age-Related Cognition Decline with Underlying Mechanisms in Alzheimer's Disease. J. Alzheimers Dis. 2020, 75, 385-395. [CrossRef]

96. Whitesides, G.M. The Origins and the Future of Microfluidics. Nat. Cell Biol. 2006, 442, 368-373. [CrossRef]

97. Xia, Y.; Whitesides, G.M. Soft Lithography. Angew. Chem. Int. Ed. 1998, 37, 550-575. [CrossRef]

98. Whitesides, G.M.; Ostuni, E.; Takayama, S.; Jiang, X.; Ingber, D.E. Soft Lithography in Biology and Biochemistry. Annu. Rev. Biomed. Eng. 2001, 3, 335-373. [CrossRef] [PubMed]

99. Folch, A.; Toner, M. Cellular Micropatterns on Biocompatible Materials. Biotechnol. Prog. 1998, 14, 388-392. [CrossRef]

100. Duffy, D.C.; McDonald, J.C.; Schueller, O.J.A.; Whitesides, G.M. Rapid Prototyping of Microfluidic Systems in Poly(Dimethylsiloxane). Anal. Chem. 1998, 70, 4974-4984. [CrossRef]

101. Taylor, A.M.; Dieterich, D.C.; Ito, H.T.; Kim, S.A.; Schuman, E.M. Microfluidic Local Perfusion Chambers for the Visualization and Manipulation of Synapses. Neuron 2010, 66, 57-68. [CrossRef] [PubMed]

102. Van Midwoud, P.M.; Janse, A.; Merema, M.T.; Groothuis, G.M.M.; Verpoorte, E. Comparison of Biocompatibility and Adsorption Properties of Different Plastics for Advanced Microfluidic Cell and Tissue Culture Models. Anal. Chem. 2012, 84, 3938-3944. [CrossRef] [PubMed]

103. Kim, S.M.; Lee, S.H.; Suh, K.Y. Cell Research with Physically Modified Microfluidic Channels: A Review. Lab Chip 2008, 8, 1015-1023. [CrossRef] [PubMed]

104. Sonnen, K.F.; Merten, C.A. Microfluidics as an Emerging Precision Tool in Developmental Biology. Dev. Cell 2019, 48, $293-311$. [CrossRef] [PubMed]

105. Duncombe, T.A.; Tentori, A.M.; Herr, A.E. Microfluidics: Reframing Biological Enquiry. Nat. Rev. Mol. Cell Biol. 2015, 16, 554-567.

106. Dittrich, P.S.; Manz, A. Lab-on-a-Chip: Microfluidics in Drug Discovery. Nat. Rev. Drug Discov. 2006, 5, 210-218. [CrossRef] [PubMed]

107. Ying, L.; Wang, Q. Microfluidic Chip-Based Technologies: Emerging Platforms for Cancer Diagnosis. BMC Biotechnol. 2013, 13, 76. [CrossRef]

108. Chin, C.D.; Laksanasopin, T.; Cheung, Y.K.; Steinmiller, D.; Linder, V.; Parsa, H.; Wang, J.; Moore, H.; Rouse, R.; Umviligihozo, G.; et al. Microfluidics-Based Diagnostics of Infectious Diseases in the Developing World. Nat. Med. 2011, 17, 1015-1019. [CrossRef] [PubMed]

109. Tay, A.; Pavesi, A.; Yazdi, S.R.; Lim, C.T.; Warkiani, M.E. Advances in Microfluidics in Combating Infectious Diseases. Biotechnol. Adv. 2016, 34, 404-421. [CrossRef]

110. Reboud, J.; Xu, G.; Garrett, A.; Adriko, M.; Yang, Z.; Tukahebwa, E.M.; Rowell, C.; Cooper, J.M. Paper-Based Microfluidics for DNA Diagnostics of Malaria in Low Resource Underserved Rural Communities. Proc. Natl. Acad. Sci. USA 2019, 116, 4834-4842. [CrossRef]

111. Vadivelu, R.; Kashaninejad, N.; Sreejith, K.R.; Bhattacharjee, R.; Cock, I.; Nguyen, N.T. Cryoprotectant-Free Freezing of Cells Using Liquid Marbles Filled with Hydrogel. ACS Appl. Mater. Interfaces 2018, 10, 43439-43449. [CrossRef]

112. Avrămescu, R.E.; Ghica, M.V.; Dinu-Pîrvu, C.; Udeanu, D.I.; Popa, L. Liquid Marbles: FromIndustrial to Medical Applications. Molecules 2018, 23, 1120. [CrossRef] [PubMed]

113. Wang, H.; Chen, L.; Sun, L. Digital microfluidics: A promising technique for biochemical applications. Front. Mech. Eng. 2017, 12, 510-525. [CrossRef] 
114. Shembekar, N.; Chaipan, C.; Utharala, R.; Merten, C.A. Droplet-based microfluidics indrug discovery, transcriptomics and high-throughput molecular genetics. Lab Chip 2016, 16, 1314-1331. [CrossRef]

115. Huang, Y.; Williams, J.C.; Johnson, S.M. Brain slice on a chip: Opportunities and challenges of applying microfluidic technology to intact tissues. Lab Chip 2012, 12, 2103-2117. [CrossRef]

116. Vedarethinam, I.; Avaliani, N.; Tonnesen, J.; Hansen, L.; Sabourin, D.; Dimaki, M.; Kokaia, M.; Dufva, M.; Svendsen, W.E.; Emneus, J.; et al. Long-term brain slice culturing in a microfluidic platform. In Proceedings of the 15th International Conference on Miniaturized Systems for Chemistry and Life Sciences, Seattle, WA, USA, 2-6 October 2011.

117. Astolfi, M.; Péant, B.; Lateef, M.A.; Rousset, N.; Kendall-Dupont, J.; Carmona, E.; Monet, F.; Saad, F.; Provencher, D.; Mes-Masson, A.M.; et al. Micro-dissected tumor tissues on chip: An ex vivo method for drug testing and personalized therapy. Lab Chip 2016, 16, 312-325. [CrossRef]

118. Yamada, A.; Vignes, M.; Bureau, C.; Mamane, A.; Venzac, B.; Descroix, S.; Viovy, J.L.; Villard, C.; Peyrin, J.M.; Malaquin, L. In-mold patterning and actionable axo-somatic compartmentalization for on-chip neuron culture. Lab Chip 2016, 16, 2059-2068. [CrossRef] [PubMed]

119. Tanaka, N.; Moriguchi, H.; Sato, A.; Kawai, T.; Shimba, K.; Jimbo, Y.; Tanaka, Y. Microcasting with agarose gel via degassed polydimethylsiloxane molds for repellency-guided cell patterning. RSC Adv. 2016, 6, 54754-54762. [CrossRef]

120. Knöll, B.; Weinl, C.; Nordheim, A.; Bonhoeffer, F. Stripe assay to examine axonal guidance and cell migration. Nat. Protoc. 2007, 2, 1216-1224. [CrossRef] [PubMed]

121. Qi, Z.B.; Xu, L.; Xu, Y.; Zhong, J.; Abedini, A.; Cheng, X.; Sinton, D. Disposable Silicon-Glass Microfluidic Devices: Precise, Robust and Cheap. Lab Chip 2018, 18, 3872-3880. [CrossRef]

122. Qian, J.Y.; Hou, C.W.; Li, X.J.; Jin, Z.J. Actuation Mechanism of Microvalves: A Review. Micromachines 2020, 11, 172. [CrossRef] [PubMed]

123. Friend, J.; Yeo, L. Fabrication of Microfluidic Devices Using Polydimethylsiloxane. Biomicrofluidics 2010, 4, 026502. [CrossRef] [PubMed]

124. Fujii, T. PDMS-Based Microfluidic Devices for Biomedical Applications. Microelectron. Eng. 2002, 61-62, 907-914. [CrossRef]

125. Fiorini, G.S.; Jeffries, G.D.M.; Lim, D.S.W.; Kuyper, C.L.; Chiu, D.T. Fabrication of Thermoset Polyester Microfluidic Devices and Embossing Masters Using Rapid Prototyped Polydimethylsiloxane Molds. Lab Chip 2003, 3, 158-163. [CrossRef]

126. Wu, W.I.; Sask, K.N.; Brash, J.L.; Selvaganapathy, P.R. Polyurethane-Based Microfluidic Devices for Blood Contacting Applications. Lab Chip 2012, 12, 960-970. [CrossRef]

127. Liu, K.; Fan, Z.H. Thermoplastic Microfluidic Devices and Their Applications in Protein and DNA Analysis. Analyst 2011, 136, 1288-1297. [CrossRef]

128. Gencturk, E.; Mutlu, S.; Ulgen, K.O. Advances in microfluidic devices made fromthermoplastics used in cell biology and analyses. Biomicrofluidics 2017, 11, 051502. [CrossRef] [PubMed]

129. Ertl, P. Recent Advances of Biologically Inspired 3D Microfluidic Hydrogel Cell Culture Systems. Cell Biol. Cell Metab. 2015, 2, 1-14. [CrossRef]

130. Morteza, B.; Mohseni, N.; Moghtader, M. An Introduction to Hydrogels and Some Recent Applications; IntechOpen, 2016.

131. Li, X.; Ballerini, D.R.; Shen, W. A Perspective on Paper-Based Microfluidics: Current Status and Future Trends. Biomicrofluidics 2012, 6, 011301. [CrossRef]

132. Esch, E.W.; Bahinski, A.; Huh, D. Organs-on-Chips at the Frontiers of Drug Discovery. Nat. Rev. Drug Discov. 2015, 14, 248-260. [CrossRef]

133. Bhattacharjee, N.; Urrios, A.; Kang, S.; Folch, A. The Upcoming 3D-Printing Revolution in Microfluidics. Lab Chip 2016, 16, 1720-1742. [CrossRef] [PubMed]

134. Luni, C.; Serena, E.; Elvassore, N. Human-on-Chip for Therapy Development and Fundamental Science. Curr. Opin. Biotechnol. 2014, 25, 45-50. [CrossRef]

135. Zhang, C.; Zhao, Z.; Abdul Rahim, N.A.; Van Noort, D.; Yu, H. Towards a Human-on-Chip: Culturing Multiple Cell Types on a Chip with Compartmentalized Microenvironments. Lab Chip 2009, 9, 3185-3192. [CrossRef] [PubMed]

136. Baudoin, R.; Corlu, A.; Griscom, L.; Legallais, C.; Leclerc, E. Trends in the Development of Microfluidic Cell Biochips for in vitro Hepatotoxicity. Toxicol. Vitr. 2007, 21, 535-544. [CrossRef] [PubMed]

137. Osaki, T.; Shin, Y.; Sivathanu, V.; Campisi, M.; Kamm, R.D. In vitro Microfluidic Models for Neurodegenerative Disorders. Adv. Healthc. Mater. 2018, 7, 1700489. [CrossRef] [PubMed]

138. Kane, K.I.W.; Jarazo, J.; Moreno, E.L.; Fleming, R.M.T.; Schwamborn, J.C. Passive Controlled Flow for Parkinson's Disease Neuronal Cell Culture in 3D Microfluidic Devices. Org. Chip 2020, 2, 100005. [CrossRef]

139. Perestrelo, A.R.; Águas, A.C.P.; Rainer, A.; Forte, G. Microfluidic Organ/Body-on-a-Chip Devices at the Convergence of Biology and Microengineering. Sensors 2015, 15, 31142-31170. [CrossRef]

140. Haring, A.P.; Sontheimer, H.; Johnson, B.N. Microphysiological Human Brain and Neural Systems-on-a-Chip: Potential Alternatives to Small Animal Models and Emerging Platforms for Drug Discovery and Personalized Medicine. Stem Cell Rev. Rep. 2017, 13, 381-406. [CrossRef]

141. Zheng, F.; Fu, F.; Cheng, Y.; Wang, C.; Zhao, Y.; Gu, Z. Organ-on-a-Chip Systems: Microengineering to Biomimic Living Systems. Small 2016, 12, 2253-2282. [CrossRef] 
142. Taylor, A.M.; Rhee, S.W.; Tu, C.H.; Cribbs, D.H.; Cotman, C.W.; Jeon, N.L. Microfluidic Multicompartment Device for Neuroscience Research. Langmuir 2003, 19, 1551-1556. [CrossRef]

143. Park, J.; Lee, B.K.; Jeong, G.S.; Hyun, J.K.; Lee, C.J.; Lee, S.H. Three-Dimensional Brain-on-a-Chip with an Interstitial Level of Flow and Its Application as an in vitro Model of Alzheimer's Disease. Lab Chip 2015, 15, 141-150. [CrossRef] [PubMed]

144. Park, J.; Wetzel, I.; Marriott, I.; Dréau, D.; D’Avanzo, C.; Kim, D.Y.; Tanzi, R.E.; Cho, H. A 3D Human Triculture System Modeling Neurodegeneration and Neuroinflammation in Alzheimer's Disease. Nat. Neurosci. 2018, 21, 941-951. [CrossRef] [PubMed]

145. Teixeira, M.I.; Amaral, M.H.; Costa, P.C.; Lopes, C.M.; Lamprou, D.A. Recent Developments in Microfluidic Technologies for Central Nervous System Targeted Studies. Pharmaceutics 2020, 12, 1-37. [CrossRef]

146. McDonald, J.C.; Whitesides, G.M. Poly(dimethylsiloxane) as a material for fabricating microfluidic devices. Acc. Chem. Res. 2002, 35, 491-499. [CrossRef]

147. Katsikoudi, A.; Ficulle, E.; Cavallini, A.; Sharman, G.; Guyot, A.; Zagnoni, M.; Eastwood, B.J.; Hutton, M.; Bose, S. Quantitative Propagation of Assembled Human Tau from Alzheimer's Disease Brain in Microfluidic Neuronal Cultures. J. Biol. Chem. 2020, 295, 13079-13093. [CrossRef]

148. Shin, Y.; Choi, S.H.; Kim, E.; Bylykbashi, E.; Kim, J.A.; Chung, S.; Kim, D.Y.; Kamm, R.D.; Tanzi, R.E. Blood-Brain Barrier Dysfunction in a 3D In vitro Model of Alzheimer's Disease. Adv. Sci. 2019, 6, 1900962. [CrossRef]

149. Gupta, N.; Liu, J.R.; Patel, B.; Solomon, D.E.; Vaidya, B.; Gupta, V. Microfluidics-based 3D Cell Culture Models: Utility in Novel Drug Discovery and Delivery Research. Bioeng. Transl. Med. 2016, 1, 63-81. [CrossRef]

150. Natarajan, A.; Sethumadhavan, A.; Krishnan, U.M. Toward Building the Neuromuscular Junction: In vitro Models to Study Synaptogenesis and Neurodegeneration. ACS Omega 2019, 4, 12969-12977. [CrossRef] [PubMed]

151. Breslin, S.; O’Driscoll, L. Three-dimensional cell culture: The missing link in drug discovery. Drug Discov. Today 2013, 18, 240-249. [CrossRef] [PubMed]

152. Peyrin, J.M.; Deleglise, B.; Saias, L.; Vignes, M.; Gougis, P.; Magnifico, S.; Betuing, S.; Pietri, M.; Caboche, J.; Vanhoutte, P.; et al. Axon Diodes for the Reconstruction of Oriented Neuronal Networks in Microfluidic Chambers. Lab Chip 2011, 11, $3663-3673$. [CrossRef]

153. Gutruf, P.; Rogers, J.A. Implantable, Wireless Device Platforms for Neuroscience Research. Curr. Opin. Neurobiol. 2018, 50, 42-49. [CrossRef]

154. Tsantoulas, C.; Farmer, C.; Machado, P.; Baba, K.; McMahon, S.B.; Raouf, R. Probing Functional Properties of Nociceptive Axons Using a Microfluidic Culture System. PLoS ONE 2013, 8, 80722. [CrossRef] [PubMed]

155. Douville, N.J.; Tung, Y.C.; Li, R.; Wang, J.D.; El-Sayed, M.E.H.; Takayama, S. Fabrication of Two-Layered Channel System with Embedded Electrodes to Measure Resistance across Epithelial and Endothelial Barriers. Anal. Chem. 2010, 82, $2505-2511$. [CrossRef] [PubMed]

156. Poon, W.W.; Blurton-Jones, M.; Tu, C.H.; Feinberg, L.M.; Chabrier, M.A.; Harris, J.W.; Jeon, N.L.; Cotman, C.W. $\beta$-Amyloid Impairs Axonal BDNF Retrograde Trafficking. Neurobiol. Aging 2011, 32, 821-833. [CrossRef] [PubMed]

157. Jackson, E.L.; Lu, H. Three-Dimensional Models for Studying Development and Disease: Moving on from Organisms to Organs-on-a-Chip and Organoids. Integr. Biol. 2016, 8, 672-683. [CrossRef]

158. Ren, Y.; Kunze, A.; Renaud, P. Compartmentalized microfluidics for in vitro Alzheimer's disease studies. Microfluidic and Compartmentalized Platforms for Neurobiological Research. Neuromethods 2015, 103, 197-215.

159. Southam, K.A.; King, A.E.; Blizzard, C.A.; McCormack, G.H.; Dickson, T.C. Microfluidic Primary Culture Model of the Lower Motor Neuron-Neuromuscular Junction Circuit. J. Neurosci. Methods 2013, 218, 164-169. [CrossRef]

160. Neto, E.; Alves, C.J.; Sousa, D.M.; Alencastre, I.S.; LourençO, A.H.; Leitão, L.; Ryu, H.R.; Jeon, N.L.; Fernandes, R.; Aguiar, P.; et al. Sensory Neurons and Osteoblasts: Close Partners in a Microfluidic Platform. Integr. Biol. 2014, 6, 586-595. [CrossRef]

161. Sundararaghavan, H.G.; Monteiro, G.A.; Firestein, B.L.; Shreiber, D.I. Neurite Growth in 3D Collagen Gels with Gradients of Mechanical Properties. Biotechnol. Bioeng. 2009, 102, 632-643. [CrossRef]

162. Ionescu, A.; Zahavi, E.E.; Gradus, T.; Ben-Yaakov, K.; Perlson, E. Compartmental Microfluidic System for Studying Muscle-Neuron Communication and Neuromuscular Junction Maintenance. Eur. J. Cell Biol. 2016, 95, 69-88. [CrossRef]

163. Robertson, G.; Bushell, T.J.; Zagnoni, M. Chemically Induced Synaptic Activity between Mixed Primary Hippocampal Co-Cultures in a Microfluidic System. Integr. Biol. 2014, 6, 636-644. [CrossRef]

164. Griciuc, A.; Serrano-Pozo, A.; Parrado, A.R.; Lesinski, A.N.; Asselin, C.N.; Mullin, K.; Hooli, B.; Choi, S.H.; Hyman, B.T.; Tanzi, R.E. Alzheimer's disease risk gene CD33 inhibits microglial uptake of amyloid beta. Neuron 2013, 78, 631-643. [CrossRef] [PubMed]

165. Bianco, F.; Tonna, N.; Lovchik, R.D.; Mastrangelo, R.; Morini, R.; Ruiz, A.; Delamarche, E.; Matteoli, M. Overflow Microfluidic Networks: Application to the Biochemical Analysis of Brain Cell Interactions in Complex Neuroinflammatory Scenarios. Anal. Chem. 2012, 84, 9833-9840. [CrossRef] [PubMed]

166. Deleglise, B.; Lassus, B.; Soubeyre, V.; Alleaume-Butaux, A.; Hjorth, J.J.; Vignes, M.; Schneider, B.; Brugg, B.; Viovy, J.L.; Peyrin, J.M. Synapto-Protective Drugs Evaluation in Reconstructed Neuronal Network. PLoS ONE 2013, 8, e71103. [CrossRef]

167. De Oliveira, T.R.; Erbereli, C.R.; Manzine, P.R.; Magalhães, T.N.C.; Balthazar, M.L.F.; Cominetti, M.R.; Faria, R.C. Early Diagnosis of Alzheimer's Disease in Blood Using a Disposable Electrochemical Microfluidic Platform. ACS Sens. 2020, 5, 1010-1019. [CrossRef] [PubMed] 
168. Islam, K.; Jang, Y.C.; Chand, R.; Jha, S.K.; Lee, H.H.; Kim, Y.S. Microfluidic Biosensor for $\beta$-Amyloid(1-42) Detection Using Cyclic Voltammetry. J. Nanosci. Nanotechnol. 2011, 11, 5657-5662. [CrossRef]

169. Yang, F.; Liao, X.; Tian, Y.; Li, G. Exosome Separation Using Microfluidic Systems: Size-Based, Immunoaffinity-Based and Dynamic Methodologies. Biotechnol. J. 2017, 12, 12. [CrossRef]

170. Cohen, M.S.; Orth, C.B.; Kim, H.J.; Jeon, N.L.; Jaffrey, S.R. Neurotrophin-Mediated Dendrite-to-Nucleus Signaling Revealed by Microfluidic Compartmentalization of Dendrites. Proc. Natl. Acad. Sci. USA 2011, 108, 11246-11251. [CrossRef]

171. Jorfi, M.; D'Avanzo, C.; Kim, D.Y.; Irimia, D. Three-Dimensional Models of the Human Brain Development and Diseases. Adv. Healthc. Mater. 2018, 7, 1002. [CrossRef]

172. Yang, I.H.; Gary, D.; Malone, M.; Dria, S.; Houdayer, T.; Belegu, V.; McDonald, J.W.; Thakor, N. Axon Myelination and Electrical Stimulation in a Microfluidic, Compartmentalized Cell Culture Platform. NeuroMolecular Med. 2012, 14, 112-118. [CrossRef]

173. Kunze, A.; Meissner, R.; Brando, S.; Renaud, P. Co-Pathological Connected Primary Neurons in a Microfluidic Device for Alzheimer Studies. Biotechnol. Bioeng. 2011, 108, 2241-2245. [CrossRef]

174. Hosie, K.A.; King, A.E.; Blizzard, C.A.; Vickers, J.C.; Dickson, T.C. Chronic Excitotoxin-Induced Axon Degeneration in a Compartmented Neuronal Culture Model. ASN Neuro 2012, 4, 47-57. [CrossRef]

175. Edington, C.D.; Chen, W.L.K.; Geishecker, E.; Kassis, T.; Soenksen, L.R.; Bhushan, B.M.; Freake, D.; Kirschner, J.; Maass, C.; Tsamandouras, N.; et al. Interconnected Microphysiological Systems for Quantitative Biology and Pharmacology Studies. Sci. Rep. 2018, 8, 4530. [CrossRef]

176. Lee, J.S.; Park, C.B. Microfluidic Dissociation and Clearance of Alzheimer's $\beta$-Amyloid Aggregates. Biomaterials 2010, 31, 6789-6795. [CrossRef] [PubMed]

177. Hong, N.; Joo, S.; Nam, Y. Characterization of Axonal Spikes in Cultured Neuronal Networks Using Microelectrode Arrays and Microchannel Devices. IEEE Trans. Biomed. Eng. 2017, 64, 492-498.

178. Lewandowska, M.K.; Bakkum, D.J.; Rompani, S.B.; Hierlemann, A. Recording Large Extracellular Spikes in Microchannels along Many Axonal Sites from Individual Neurons. PLoS ONE 2015, 10. [CrossRef] [PubMed]

179. Habibey, R.; Latifi, S.; Mousavi, H.; Pesce, M.; Arab-Tehrany, E.; Blau, A. A Multielectrode Array Microchannel Platform Reveals Both Transient and Slow Changes in Axonal Conduction Velocity. Sci. Rep. 2017, 7, 8558. [CrossRef] [PubMed]

180. Dworak, B.J.; Wheeler, B.C. Novel MEA Platform with PDMS Microtunnels Enables the Detection of Action Potential Propagation from Isolated Axons in Culture. Lab Chip 2009, 9, 404-410. [CrossRef] [PubMed]

181. Stoothoff, W.; Jones, P.B.; Spires-Jones, T.L.; Joyner, D.; Chhabra, E.; Bercury, K.; Fan, Z.; Xie, H.; Bacskai, B.; Edd, J.; et al. Differential Effect of Three-Repeat and Four-Repeat Tau on Mitochondrial Axonal Transport. J. Neurochem. 2009, 111, 417-427. [CrossRef]

182. Deleglise, B.; Magnifico, S.; Duplus, E.; Vaur, P.; Soubeyre, V.; Belle, M.; Vignes, M.; Viovy, J.L.; Jacotot, E.; Peyrin, J.M.; et al. $\beta$-Amyloid Induces a Dying-Back Process and Remote Trans-Synaptic Alterations in a Microfluidic-Based Reconstructed Neuronal Network. Acta Neuropathol. Commun. 2014, 2, 145.

183. Cho, H.; Hashimoto, T.; Wong, E.; Hori, Y.; Wood, L.B.; Zhao, L.; Haigis, K.M.; Hyman, B.T.; Irimia, D. Microfluidic Chemotaxis Platform for Differentiating the Roles of Soluble and Bound Amyloid- $\beta$ on Microglial Accumulation. Sci. Rep. 2013, 3, 1823. [CrossRef]

184. Choi, I.; Huh, Y.S.; Erickson, D. Size-Selective Concentration and Label-Free Characterization of Protein Aggregates Using a Raman Active Nanofluidic Device. Lab Chip 2011, 11, 632-638. [CrossRef]

185. Park, J.; Koito, H.; Li, J.; Han, A. Microfluidic Compartmentalized Co-Culture Platform for CNS Axon Myelination Research. Biomed. Microdevices 2009, 11, 1145-1153. [CrossRef]

186. Hosmane, S.; Yang, I.H.; Ruffin, A.; Thakor, N.; Venkatesan, A. Circular Compartmentalized Microfluidic Platform: Study of Axon-Glia Interactions. Lab Chip 2010, 10, 741-747. [CrossRef]

187. Taylor, A.M.; Rhee, S.W.; Jeon, N.L. Microfluidic Chambers for Cell Migration and Neuroscience Research. Methods Mol. Biol. 2006, 321, 167-177. [PubMed]

188. Goral, V.; Hsieh, Y.-C.; Petzold, O.; Faris, R.; Yuen, P.K. Hot Embossing of Plastic Microfluidic Devices Using Poly(Dimethylsiloxane) Molds. J. Micromech. Microeng. 2011, 21, 017002. [CrossRef]

189. Chumbimuni-Torres, K.Y.; Coronado, R.E.; Mfuh, A.M.; Castro-Guerrero, C.; Silva, M.F.; Negrete, G.R.; Bizios, R.; Garcia, C.D. Adsorption of Proteins to Thin-Films of PDMS and Its Effect on the Adhesion of Human Endothelial Cells. RSC Adv. 2011, 1, 706-714. [CrossRef] [PubMed]

190. Gomez-Sjoberg, R.; Leyrat, A.; Houseman, B.; Shokat, K.; Quake, S. Biocompatibility and Reduced Drug Absorption of Sol-GelTreated Poly(Dimethyl Siloxane) for Microfluidic Cell Culture Applications. Anal. Chem. 2010, 82, 8954-8960. [CrossRef]

191. Wang, X.; Yi, L.; Mukhitov, N.; Schrell, A.M.; Dhumpa, R.; Roper, M.G. Microfluidics-to-Mass Spectrometry: A Review of Coupling Methods and Applications. J. Chromatogr. A 2015, 1382, 98-116. [CrossRef]

192. Ward, K.; Fan, Z.H. Mixing in Microfluidic Devices and Enhancement Methods. J. Micromech. Microeng. $2015,25,094001$. [CrossRef] [PubMed]

193. Oxford, A.E.; Stewart, E.S.; Rohn, T.T. Clinical Trials in Alzheimer's Disease: A Hurdle in the Path of Remedy. Int. J. Alzheimers Dis. 2020, 2020, 5380346. [CrossRef] [PubMed] 